Article

\title{
Formulation of Biochar-Based Phosphorus Fertilizer and Its Impact on Both Soil Properties and Chickpea Growth Performance
}

\author{
Farman Wali ${ }^{1}$, Muhammad Naveed ${ }^{1, *} \mathbb{D}$, Muhammad Asaad Bashir ${ }^{1,2}{ }^{-}$, Muhammad Asif ${ }^{3}$, \\ Zulfiqar Ahmad ${ }^{1}$, Jawaher Alkahtani ${ }^{4}$, Mona S. Alwahibi ${ }^{4}$ and Mohamed Soliman Elshikh ${ }^{4}$ \\ 1 Institute of Soil and Environmental Sciences, University of Agriculture, Faisalabad 38040, Pakistan; \\ walithree3@gmail.com (F.W.); m.asaadbashir@gmail.com (M.A.B.); zulfiqar1409@gmail.com (Z.A.) \\ 2 Department of Soil Science, University College of Agriculture and Environmental Sciences, \\ The Islamia University of Bahawalpur, Bahawalpur 63100, Pakistan \\ 3 Institute of Horticultural Sciences, University of Agriculture, Faisalabad 38040, Pakistan; \\ roymasif@yahoo.co.in \\ 4 Department of Botany and Microbiology, College of Science, King Saud University, Riyadh 11451, \\ Saudi Arabia; jslqahtani@ksu.edu.sa (J.A.); malwahibi@ksu.edu.sa (M.S.A.); melshikh@ksu.edu.sa (M.S.E.) \\ * Correspondence: muhammad.naveed@uaf.edu.pk
}

Received: 13 October 2020; Accepted: 12 November 2020; Published: 16 November 2020

\begin{abstract}
There is no alternative to phosphorus $(\mathrm{P})$ in agriculture as it is second most important plant nutrient after nitrogen. Mineral $P$ fertilizers are derived from rock phosphate (RP) which is finite, non-renewable and geographically restricted to a few countries, thus its shortage likely affects agriculture in near future as the world population is growing at a greater pace. This could increase $P$ inputs in agriculture in order to meet rising food demands which may result in the depletion of $\mathrm{RP}$ reserves. Furthermore, $\mathrm{P}$ losses from farmlands in case of mineral $\mathrm{P}$ fertilizers also demands the sustainable use of $\mathrm{P}$ not only because of its finite resources but also the environmental concerns associated with $P$ fertilization such as eutrophication. The present study was designed to formulate biochar-based $P$ fertilizer that would help in the sustainable use of $P$ fertilizer. Biochar(s) were prepared using wheat straw at $350-400{ }^{\circ} \mathrm{C}$ pyrolytic temperature followed by enrichment with Di-ammonium phosphate (DAP) taking into account all possible combination of DAP to biochar on the $\mathrm{w} / \mathrm{w}$ basis $(0: 100,25: 75,50: 50,75: 25$ and 100:0). Enrichment was carried out using two different methods i.e., phosphorus enriched biochar $\left(\mathrm{PEB}_{1}\right)$ by hot method and cold method $\left(\mathrm{PEB}_{2}\right)$. An incubation experiment was performed to assess the impact of each biochar on selected properties of soil. The treatments were organized in factorial arrangement under complete randomized design (CRD) with three replications. Both the amendments were applied at rate of $1 \%$ of dry soil on a $w / w$ basis. A significant increase in soil extractable $\mathrm{P}$ and total nitrogen $(\mathrm{N})$ was recorded for the ratio 50:50 as compared to control as well of rest of treatments. Similarly, high organic contents were found for both $\mathrm{PEB}_{1}$ and $\mathrm{PEB}_{2}$ at the ratio 50:50. An incubation experiment was followed by pot trial using 50:50 for both $\mathrm{PEB}_{1}$ and $\mathrm{PEB}_{2}$ and split doses of recommended $\mathrm{P}$ were applied $(0 \%, 25 \%, 50 \%$ and $100 \%$ ) with a control under CRD with three replications using chickpea as test crop. Both $\mathrm{PEB}_{1}$ and $\mathrm{PEB}_{2}$ with $50 \% \mathrm{P}$ have significantly improved crop growth, yield, nodulation, and plant physiological and chemical parameters as compared to a recommended dose of $P$ alone. The result may imply that the integration of P-enriched biochar and chemical fertilizer could be an effective approach to improve chickpea production and soil properties.
\end{abstract}

Keywords: biochar; phosphorus; nodulation; soil health; chickpea 


\section{Introduction}

The world's population is increasing at an alarming rate and it has become a global challenge to feed 9 billion people by 2050 [1]. Phosphorus (P)—the second most important plant nutrient; exploited from the Earth's crust as rock phosphate (RP)—is an essential reserve to ensure global food security as there is no alternative to $\mathrm{P}$ in agriculture. Since the world population is growing fast therefore food demand rises, thus more $\mathrm{P}$ is required in the near future to guarantee that global food resources will support the coming generations. This increase in $\mathrm{P}$ demand would result in the excavation of RP at much higher rates as $80 \%$ of RP is mined for the production of $\mathrm{P}$ fertilizer [2]. Additionally, deposits of RP are unevenly distributed geographically because $85 \%$ of its reserves are restricted to Morocco, China, US, Jordan and South Africa [3]. Since RP is non-renewable and finite, its shortage would be a great threat, particularly for the countries lacking RP reserves and depending on imports to fulfill their $\mathrm{P}$ requirements. The sustainable use of $\mathrm{P}$ is pressing issue not only because of its finite resources but also due to environmental concerns associated with its fertilization, as the green revolution has suggested the one-way flow of $P$ from its mines to waste dumps or water bodies causing eutrophication that disturbs aquatic population, biodiversity and the aquatic food chain [4].

Furthermore, $\mathrm{P}$ applied in the form of mineral fertilizer is prone to losses in both acid and calcareous soils because of $\mathrm{P}$ fixation. When soluble $\mathrm{P}$ is added to the soil then it reacts with soil constituents to form less soluble phosphates. In the case of calcareous soils (high in $\mathrm{Ca}^{2+}$ ), the solubility of $\mathrm{P}$ will be reduced due to its reaction with $\mathrm{Ca}^{2+}[5]$ while in acid soils, its solubility is reduced due to the reaction of $\mathrm{P}$ with $\mathrm{Fe}$ and $\mathrm{Al}$ oxides [6]. Only a small portion of applied $\mathrm{P}$ is available to plants while its major chunk $(80 \%)$ is prone to such fixations [7]. This fixed P could pollute underground water in case of leaching from farmlands or it could contaminate surface water in case of runoff since excess $\mathrm{P}$ in water increases the growth of algal blooms which will reduce the dissolved oxygen and block sunlight which in turn creates anoxic conditions in waters [8]. Thus, strategies should be devised to ensure the sustainable use of $P$.

Several technologies were developed to enhance P use efficiency: for example, the coating of $P$ fertilizer with polymers $[9,10]$, incorporation of $P$ fertilizer into humic substances [11] and the incorporation of mineral P fertilizers into compost $[12,13]$. Recently, biochar-carbon-rich compound obtained through burning biomass in the absence or limited supply of oxygen [14] — has gained importance as a soil amendment which could be used for the same purpose. There is the possibility of producing biochar in the presence of mineral additives which has increased the bioavailability of nutrients [15]. However, biochar may contain polycyclic aromatic hydrocarbons (PAHs). For example, biochar made from coniferous residues contains $9113 \mu \mathrm{g} / \mathrm{kg}$ and wood residues contain 355,295 $\mu \mathrm{g} / \mathrm{kg}$ PAHs [16]. The presence of PAHs in biochar may present a human health risk as they are carcinogenic [17] and they can be accumulated by vegetables when grown on soils amended with biochars containing PAHs in high amounts [18]. However, the concentration of PAHs in the biochar is highly dependent upon the type of feedstock [19] and temperature on which pyrolysis is carried out [20], thus one can minimize the impact of PAHs by opting suitable feedstock and pyrolytic temperature.

It is well established that the application of biochar with blended $\mathrm{N}$ fertilizer resulted in significant improvement in the yield of reddish [21]. Similarly, the application of biochar with mineral NPK fertilizer has significantly improved the yield of peanut, maize and cowpea [22]. Biochar enriched with animal urine was found to increase the yield of pumpkin [23]. Furthermore, biochar could also improve the physical, chemical and biological properties of soil as the addition of biochar has improved soil aeration, structure, nutrient retention, water holding capacity, and provides habitat to microbial population $[24,25]$. Thus, the enrichment of biochar with nutrients could be a satisfactory technique in order to enhance P use efficiency, however, this field remains to be fully explored and systematized studies should be conducted in order to determine the best way to carry out such enrichments.

In the current study, it was hypothesized that the effectiveness of mineral $P$ fertilizer would be enhanced by impregnating a P source (Di-ammonium phosphate (DAP)) into biochar, and consequently, optimum crop yields would be obtained with minimum P inputs (mineral fertilizer). The specific objectives were to 
optimize the proper impregnation ratio ( $w / w)$ of the P source (DAP) to biochar; and to assess the effectiveness of phosphorus-enriched biochar through pot trial with a split dose of mineral $\mathrm{P}$ fertilizer.

\section{Materials and Methods}

\subsection{Sampling and Analysis of Experimental Soil}

For the determination of selected properties of soil (Supplementary Table S1), a soil sample was taken randomly from a field area, Institute of Soil and Environmental Sciences, University of Agriculture Faisalabad Pakistan, at a depth of $0-15 \mathrm{~cm}$. The soil of this site belongs to the Lyallpur series with the great group Typic Calciargid (USDA taxonomic system). The sample was air dried and ground to pass through a $<2 \mathrm{~mm}$ sieve prior to the analysis. Soil EC and $\mathrm{pH}$ were determined by making a 1:1 $(w / v)$ suspension in distilled water. The saturation percentage of soil was determined by making a soil saturated paste. Extractable phosphorus $\left(\mathrm{mg} \mathrm{kg}^{-1}\right)$ was determined using a spectrophotometer at a wavelength of $882 \mathrm{~nm}$ [26]. Organic carbon was calculated through manual titration form which organic matter (\%) was estimated, following the protocol described by [27]. Total nitrogen was determined using the method as described by Keeney and Nelson [28]; and Calcium carbonate was estimated following the protocol described by [29].

\subsection{Chemical Analysis of Biochar Used for Enrichment}

The electrical conductivity (EC) and $\mathrm{pH}$ of biochar were determined by making its solution in deionized water at a ratio of 1:20 (w/v) followed by shaking on a mechanical shaker for $90 \mathrm{~min}$ [30]. For the determination of a nutrient $(\mathrm{P}, \mathrm{K}, \mathrm{Ca}$ and $\mathrm{Mg}$ ) concentration, extraction was done by digesting biochar in hydrogen peroxide $\left(\mathrm{H}_{2} \mathrm{O}_{2}\right)$ and sulfuric acid $\left(\mathrm{H}_{2} \mathrm{SO}_{4}\right)$ [31]. After digestion, calcium (Ca) and magnesium (mg) were determined in an atomic absorption spectrometer (AAnalyst, Perkinelmer, Norwalk, USA). Furthermore, potassium (K) was determined using a flame photometer (PFP7, Jenway, Essex, UK) while P was determined using a UV-visible spectrophotometer (UV-1201, Shimadzu, Tokyo, Japan). The $\mathrm{N}$ contents were determined using a carbon, hydrogen and nitrogen $(\mathrm{CHN})$ elemental analyzer (Carlo-Erba NA-1500) (Supplementary Table S2).

\subsection{Preparation and Enrichment of Biochar}

Biochar was prepared using wheat straw. Physical impurities were removed, and feedstock was ground to a uniform size followed by oven drying. Pyrolysis was carried out in an automated furnace at a temperature of $350-400{ }^{\circ} \mathrm{C}$ with the resident time of $1 \mathrm{~h}$ and at constant heat rate of $10{ }^{\circ} \mathrm{C} \mathrm{min}^{-1}$ [32]. DAP was used as a P source for the purpose of enrichment. Enrichment was carried out using two methods namely the hot method $\left(\mathrm{PEB}_{1}\right)$ and cold method $\left(\mathrm{PEB}_{2}\right)$. For each method, five types of enriched biochar (1 kg each) were made taking into account all possible ratios of DAP to biochar $(0: 100,25: 75,50: 50,75: 25$ and 100:0) on a $w / w$ basis. In the hot method, for the preparation of 0:100, $900 \mathrm{~g}$ hot biochar was poured into a bucket containing $100 \mathrm{~g}$ sterilized sand; for 25:75, $675 \mathrm{~g}$ hot biochar was added to a bucket containing $225 \mathrm{~g}$ ground DAP and $100 \mathrm{~g}$ sterilized sand; for 50:50, $450 \mathrm{~g}$ hot biochar was added to a bucket containing $450 \mathrm{~g}$ ground DAP and $100 \mathrm{~g}$ sterilized sand; for 75:25, $225 \mathrm{~g}$ hot biochar was added to a bucket containing $675 \mathrm{~g}$ ground DAP and $100 \mathrm{~g}$ sterilized sand; and for 100:0, $900 \mathrm{~g}$ DAP (heated below $100{ }^{\circ} \mathrm{C}$ ) was added to a bucket containing $100 \mathrm{~g}$ sterilized sand. Warm distilled water was sprinkled over the mixture(s) for proper dissolution. After enrichment, the biochar(s) were oven dried and stored in airtight containers for further use. The same protocol was followed in the cold method; however, a requisite amount of DAP was added when the biochar(s) had been cooled to room temperature $\left(25^{\circ} \mathrm{C}\right)$.

\subsection{Incubation Experiment}

The incubation study was conducted over a period of 30 days at the Soil and Environmental Microbiology Laboratory, Institute of Soil and Environmental Science, University of Agriculture 
Faisalabad, Pakistan. The treatments were arranged factorially under complete randomized design (CRD) with three replications. The factors included biochar types $\left(\mathrm{PEB}_{1}\right.$ and $\left.\mathrm{PEB}_{2}\right)$ and the impregnation ratio of DAP to biochar with the control (0, 0:100, 25:75, 50:50, 75:25, and 100:0). Commercial plastic cups with the capacity to hold $0.5 \mathrm{~kg}$ soil were used in the experiment. For each treatment, $1 \mathrm{~kg}$ of soil was taken in a plastic bag and its respective treatment at rate of $1 \%$ of dry soil on a $w / w$ basis was added, and the amended soil was divided into two equal parts $(0.5 \mathrm{~kg}$ each) and transferred to plastic cups in order to record data after 15 and 30 days, respectively. All the cups were incubated at $25^{\circ} \mathrm{C}$. Distilled water was used to maintain water contents and was applied on the basis of saturation percentage. The weight of each cup was recorded after every third day with the addition of water to maintain constant moisture contents $(35.50 \%)$ during the whole experiment. Plastic cups were removed after 15 and 30 days, respectively, and data were recorded for EC and pH by making a 1:1 (w/w) suspension of soil. Extractable phosphorus $\left(\mathrm{mg} \mathrm{kg}^{-1}\right)$ was determined using the spectrophotometer at a wavelength of $882 \mathrm{~nm}$ [26]. Total nitrogen was determined using the method as described by Keeney and Nelson [28]. Organic matter (\%) was estimated by titration method [27].

\subsection{Pot Trial}

A pot study was piloted at the wire house Institute of Soil and Environmental Science, University of Agriculture Faisalabad, Pakistan, using both enriched biochars $\left(\mathrm{PEB}_{1}\right.$ and $\left.\mathrm{PEB}_{2}\right)$ with $\mathrm{DAP}$ to biochar ratio of 50:50. Biochar type 50:50 was selected because maximum extractable phosphorus was found at this ratio after 30 days of incubation. Treatments were arranged factorially under CRD with three replicates. The factors include a biochar type with the control $\left(0, \mathrm{PEB}_{1}\right.$ and $\left.\mathrm{PEB}_{2}\right)$ and a split dose of recommended $\mathrm{P}$ with the control (0, 25\%,50\% and 100\%). Enriched biochar(s) were added to all treatments at a rate of $1 \%$ of dry soil on a $w / w$ basis and mixed thoroughly before sowing. The recommended dose of nitrogen $\left(15 \mathrm{~kg} \mathrm{ha}^{-1}\right)$ and potassium $\left(60 \mathrm{~kg} \mathrm{ha}^{-1}\right)$ was added to all the treatments and the split dose $(0 \%, 25 \%, 50 \%$, and $100 \%)$ of recommended $\mathrm{P}\left(60 \mathrm{~kg} \mathrm{ha}^{-1}\right)$ was also added to its respective treatment at sowing. Chickpea (Cicer arietinum L.) was used as a test crop. Sowing was done manually, and plant density was maintained at six plants pot $^{-1}$, after germination. All other agronomic practices were kept constant for all the treatments. Photosynthetic rate, transpiration rate and stomatal conductance were determined using CIRAS-3 (PP system, Amesbury, USA). Chlorophyll contents were measured using a chlorophyll content meter (CCM-200 PLUS, Opti-Sciences, Tyngsboro, Massachusetts). The total number of root nodules and nodule weight was calculated by harvesting two plants from each pot at flowering stage. At harvest, no of primary branches plant ${ }^{-1}$ were calculated by taking the average of three plants from each treatment randomly. The root/shoot length $(\mathrm{cm})$ was determined using scale. Similarly, root and shoot fresh weight $(\mathrm{g})$; root and shoot dry weight $(\mathrm{g})$; and seed yield ( $\mathrm{g}$ ) was determined using digital balance. The total number of pods per plant ${ }^{-1}$ was determined by taking the average of three random plants from each treatment. Shoot $P$ contents were measured using a spectrophotometer at wavelength $410 \mathrm{~nm}$ by taking $0.5 \mathrm{~g}$ shoot sample in $50 \mathrm{~mL}$ flask followed by the addition of $5 \mathrm{~mL} \mathrm{HNO}_{3}-\mathrm{HClO}_{4}$ mixture [33]. Shoot nitrogen contents were estimated using the Kjeldahl apparatus [34].

\subsection{Statistical Analysis}

The data obtained (from an incubation experiment as well as pot trial) were subjected to statistical analysis through the analysis of variance in order to find difference among the mean of treatments. Mean of all the treatments were compared using a Tukey honestly significant difference (HSD) at a level of significance less than 5\% [35] using computer-based software (Statistix version 8.1). 


\section{Results}

\subsection{Impact of P-Enriched Biochar on Selected Properties of Incubated Soil}

On the 15th day of incubation, it was observed that both $\mathrm{PEB}_{1}$ and $\mathrm{PEB}_{2}$ have not shown any significant effect on soil P contents at the ratio 0:100 when compared with the control (0:0) as shown in (Table 1). However, after 30 days of incubation, the same treatments significantly increased the soil $\mathrm{P}$ contents (Table 2) as compared to the control. Furthermore, an increasing trend was recorded with the addition of DAP up to the ratio 75:25. Further increase in DAP did not yield any significant results, instead the available P was reduced to the ratio 100:0. At 15th day of incubation, maximum P contents were recorded for the ratio 75:25, however, it was not significantly higher than the ratio 50:50. Similarly, P contents were found to be highest at the ratio 75:25 after 30 days of incubation but not significantly higher than 50:50. Both biochar types, i.e., $\mathrm{PEB}_{1}$ and $\mathrm{PEB}_{2}$, did not yield any significant difference in terms of the soil available $P$ contents.

For both $\mathrm{PEB}_{1}$ and $\mathrm{PEB}_{2}$, a little increase in soil total $\mathrm{N}$ was recorded where only biochar was used (0:100) as compared to the control (Table 1) after 15 days of incubation. An increasing trend was observed upon the addition of DAP up to the ratio (75:25) while further addition of DAP did not yield any significant difference, instead it decreased the total $\mathrm{N}$ at 100:0. Furthermore, statistically no significant difference was recorded between the ratios 50:50 and 75:25. The same observation was recorded after 30 days of incubation (Table 2), however, the soil total $\mathrm{N}$ was higher for all the treatments as compared to the values recorded after 15 days of incubation.

Organic matter was significantly improved by the amendment at the ratio 0:100 when compared with the control after 15 days of incubation as shown in (Table 1). Upon the addition of DAP, a decreasing trend in organic matter was recorded, and no improvement was found at the ratio 100:0 when compared with the control (0:0). With the increase in incubation period, no significant effect was recorded in terms of organic matter as a similar trend was observed after 30 days of incubation (Table 2). Similarly, both biochar types showed the same results.

Soil electrical conductivity (EC) was significantly increased by the biochar at 0:100 as compared to the control after 15 days of incubation (Table 1). An increasing trend in soil EC was recorded with the increase in DAP with the highest value recorded at the ratio 100:0. The incubation period had no significant effect on soil EC as the same observations were recorded after 30 days of incubation (Table 2). Similarly, biochar types $\left(\mathrm{PEB}_{1}\right.$ and $\left.\mathrm{PEB}_{2}\right)$ did not yield any significant difference in terms of soil EC.

In the case of soil $\mathrm{pH}$, a little reduction was observed at the ratio 0:100 after 15 days of incubation (Table 1). Upon the addition of DAP, an increasing trend was observed as compared to 0:100, however, the highest $\mathrm{pH}$ was recorded for the control (0:0). Similarly, after 30 days of incubation, a minor decrease in $\mathrm{pH}$ was recorded for all the treatments as compared to the control (0:0) as shown in Table 2. Both biochar types $\left(\mathrm{PEB}_{1}\right.$ and $\left.\mathrm{PEB}_{2}\right)$ yielded a similar response. 
Table 1. Effect of p-enriched biochar $\left(\mathrm{PEB}_{1}\right.$ and $\left.\mathrm{PEB}_{2}\right)$ on selected properties (mean \pm standard deviation) of incubated soil after 15 days of incubation.

\begin{tabular}{|c|c|c|c|c|c|c|c|c|c|c|}
\hline \multirow{2}{*}{ DAP: Biochar $(w / w)$} & \multicolumn{2}{|c|}{ Extractable Phosphorus $\left(\mathrm{mgkg}^{-1}\right)$} & \multicolumn{2}{|c|}{ Nitrogen $(\%)$} & \multicolumn{2}{|c|}{ Organic Matter (\%) } & \multicolumn{2}{|c|}{$\mathrm{EC}\left(\mathrm{dSm}^{-1}\right)$} & \multicolumn{2}{|c|}{$\mathrm{pH}$} \\
\hline & PEB $_{1}$ & $\mathrm{PEB}_{2}$ & $\mathrm{PEB}_{1}$ & $\mathrm{PEB}_{2}$ & $\mathrm{PEB}_{1}$ & $\mathrm{PEB}_{2}$ & $\mathrm{PEB}_{1}$ & $\mathrm{PEB}_{2}$ & $\mathrm{PEB}_{1}$ & $\mathrm{PEB}_{2}$ \\
\hline 0:0 (control) & $3.81 \pm 0.09^{\mathrm{d}}$ & $3.87 \pm 0.09^{\mathrm{d}}$ & $0.07 \pm 0.03^{c}$ & $0.07 \pm 0.02^{\mathrm{d}}$ & $0.55 \pm 0.05 \mathrm{de}$ & $0.55 \pm 0.07 \mathrm{de}$ & $0.58 \pm 0.02 \mathrm{~g}$ & $0.58 \pm 0.01 \mathrm{~g}$ & $8.09 \pm 0.09^{\mathrm{a}}$ & $8.08 \pm 0.03^{a}$ \\
\hline $0: 100$ & $3.92 \pm 0.04^{d}$ & $3.91 \pm 0.09^{d}$ & $0.11 \pm 0.04^{c}$ & $0.11 \pm 0.05^{c}$ & $1.07 \pm 0.08^{\mathrm{a}}$ & $1.09 \pm 0.03^{\mathrm{a}}$ & $0.72 \pm 0.02^{\mathrm{f}}$ & $0.73 \pm 0.02^{f}$ & $7.81 \pm 0.01^{d}$ & $7.82 \pm 0.02^{d}$ \\
\hline $25: 75$ & $5.41 \pm 0.35^{c}$ & $5.57 \pm 0.12 \mathrm{bc}$ & $0.60 \pm 0.03^{b}$ & $0.61 \pm 0.01^{b}$ & $0.98 \pm 0.01 \mathrm{ab}$ & $0.97 \pm 0.01 \mathrm{ab}$ & $0.96 \pm 0.03^{\mathrm{e}}$ & $0.91 \pm 0.01 \mathrm{e}$ & $7.88 \pm 0.01^{b-d}$ & $7.87 \pm 0.02^{\mathrm{cd}}$ \\
\hline $50: 50$ & $7.87 \pm 0.83^{\mathrm{a}}$ & $7.92 \pm 0.09^{\mathrm{a}}$ & $0.94 \pm 0.03^{a}$ & $0.95 \pm 0.03^{\mathrm{a}}$ & $0.84 \pm 0.02 \mathrm{bc}$ & $0.85 \pm 0.04^{b}$ & $1.08 \pm 0.02^{\mathrm{d}}$ & $1.07 \pm 0.06^{\mathrm{d}}$ & $7.96 \pm 0.03 \mathrm{bc}$ & $7.97 \pm 0.03^{b c}$ \\
\hline $75: 25$ & $8.50 \pm 0.33^{a}$ & $8.30 \pm 0.43^{\mathrm{a}}$ & $0.96 \pm 0.02^{a}$ & $0.96 \pm 0.02^{a}$ & $0.68 \pm 0.06^{\mathrm{cd}}$ & $0.66 \pm 0.08 \mathrm{de}$ & $1.27 \pm 0.01 \mathrm{bc}$ & $1.22 \pm 0.03^{c}$ & $7.98 \pm 0.01^{b}$ & $7.97 \pm 0.02^{b c}$ \\
\hline 100:0 & $6.54 \pm 0.29^{b}$ & $6.33 \pm 0.22 b c$ & $0.93 \pm 0.03^{a}$ & $0.93 \pm 0.02^{a}$ & $0.50 \pm 0.06^{\mathrm{e}}$ & $0.52 \pm 0.07 \mathrm{de}$ & $1.35 \pm 0.04^{\mathrm{a}}$ & $1.37 \pm 0.02^{\mathrm{ab}}$ & $7.97 \pm 0.02^{b c}$ & $7.97 \pm 0.02^{b c}$ \\
\hline
\end{tabular}

Mean values having different letters (in superscript) are significantly different from one another at a level of significance $<5 \%$ (Tukey $\mathrm{HSD}_{\text {test); }} \mathrm{PEB}_{1}$, biochar enriched through hot method;

$\mathrm{PEB}_{2}$, biochar enriched through cold method; DAP, diammonium phosphate; EC, electrical conductivity

Table 2. Effect of p-enriched biochar $\left(\mathrm{PEB}_{1}\right.$ and $\left.\mathrm{PEB}_{2}\right)$ on selected properties (mean \pm standard deviation) of incubated soil after 30 days of incubation.

\begin{tabular}{|c|c|c|c|c|c|c|c|c|c|c|}
\hline \multirow{2}{*}{ DAP: Biochar $(w / w)$} & \multicolumn{2}{|c|}{ Extractable Phosphorus $\left(\mathrm{mgkg}^{-1}\right)$} & \multicolumn{2}{|c|}{ Nitrogen $(\%)$} & \multicolumn{2}{|c|}{ Organic Matter (\%) } & \multicolumn{2}{|c|}{$\mathrm{EC}\left(\mathrm{dS} \mathrm{m}^{-1}\right)$} & \multicolumn{2}{|c|}{$\mathrm{pH}$} \\
\hline & PEB $_{1}$ & $\mathrm{PEB}_{2}$ & $\mathrm{PEB}_{1}$ & $\mathrm{PEB}_{2}$ & PEB $_{1}$ & $\mathbf{P E B}_{2}$ & $\mathrm{PEB}_{1}$ & $\mathrm{PEB}_{2}$ & $\mathrm{PEB}_{1}$ & $\mathrm{PEB}_{2}$ \\
\hline 0:0 (control) & $3.95 \pm 0.02 \mathrm{e}$ & $3.96 \pm 0.02^{\mathrm{e}}$ & $0.07 \pm 0.03^{c}$ & $0.07 \pm 0.02^{\mathrm{c}}$ & $0.53 \pm 0.10 \mathrm{de}$ & $0.52 \pm 0.07^{\mathrm{e}}$ & $0.58 \pm 0.07^{\mathrm{f}}$ & $0.56 \pm 0.08^{f}$ & $8.09 \pm 0.09^{a}$ & $8.08 \pm 0.03^{\mathrm{a}}$ \\
\hline $0: 100$ & $4.17 \pm 0.05^{\mathrm{d}}$ & $4.18 \pm 0.05^{\mathrm{d}}$ & $0.12 \pm 0.05^{c}$ & $0.11 \pm 0.05^{c}$ & $1.07 \pm 0.03^{\mathrm{a}}$ & $1.00 \pm 0.01 \mathrm{ab}$ & $0.72 \pm 0.01^{\mathrm{e}}$ & $0.73 \pm 0.02^{\mathrm{e}}$ & $7.81 \pm 0.01 \mathrm{~d}$ & $7.82 \pm 0.02^{\mathrm{d}}$ \\
\hline $25: 75$ & $6.01 \pm 0.03^{c}$ & $6.02 \pm 0.03^{c}$ & $0.80 \pm 0.03^{b}$ & $0.81 \pm 0.01^{b}$ & $0.91 \pm 0.01 \mathrm{bc}$ & $0.93 \pm 0.04 \mathrm{bc}$ & $0.91 \pm 0.01^{\mathrm{d}}$ & $0.92 \pm 0.01^{\mathrm{d}}$ & $7.88 \pm 0.01^{b-d}$ & $7.87 \pm 0.02^{\mathrm{cd}}$ \\
\hline $50: 50 *$ & $9.98 \pm 0.02^{\mathrm{a}}$ & $9.99 \pm 0.02^{\mathrm{a}}$ & $1.14 \pm 0.03^{\mathrm{a}}$ & $1.15 \pm 0.03^{\mathrm{a}}$ & $0.85 \pm 0.02^{c}$ & $0.84 \pm 0.04^{c}$ & $1.08 \pm 0.03^{c}$ & $1.08 \pm 0.05^{c}$ & $7.96 \pm 0.03 \mathrm{bc}$ & $7.97 \pm 0.03^{b c}$ \\
\hline $75: 25$ & $10.06 \pm 0.04^{a}$ & $\begin{array}{c}10.05 \pm 0.04 \\
\mathrm{a}\end{array}$ & $\underset{\mathrm{a}}{1.162 \pm 0.02}$ & $1.16 \pm 0.02^{\mathrm{a}}$ & $0.65 \pm 0.03 \mathrm{de}$ & $0.66 \pm 0.02^{\mathrm{d}}$ & $1.26 \pm 0.02^{b}$ & $1.22 \pm 0.02^{b}$ & $7.98 \pm 0.01^{b}$ & $7.97 \pm 0.02^{b c}$ \\
\hline 100:0 & $8.13 \pm 0.02^{b}$ & $8.18 \pm 0.02^{b}$ & $1.13 \pm 0.03^{a}$ & $1.13 \pm 0.02^{\mathrm{a}}$ & $0.53 \pm 0.01$ de & $0.52 \pm 0.02 \mathrm{de}$ & $1.39 \pm 0.03^{a}$ & $1.37 \pm 0.02^{\mathrm{a}}$ & $7.97 \pm 0.02 \mathrm{bc}$ & $7.97 \pm 0.02^{b c}$ \\
\hline
\end{tabular}

Mean values having different letters (in superscript) are significantly different from one another at a level of significance $<5 \%$ (Tukey $\mathrm{HSD}_{\text {test); }} \mathrm{PEB}_{1}$, biochar enriched through hot method;

$\mathrm{PEB}_{2}$, biochar enriched through cold method; DAP, diammonium phosphate; EC, electrical conductivity; *, treatment selected for pot trial. 


\subsection{Impact of P-Enriched Biochar on Growth, Yield and Nodulation of Chickpea}

\subsubsection{Crop Growth}

Both $\mathrm{PEB}_{1}$ and $\mathrm{PEB}_{2}$ significantly improved plant height with a $0 \%$ recommended dose of $\mathrm{P}$ (RDP) when compared with $100 \%$ RDP as shown in (Table 3). No significant difference was recorded between the biochar types. Furthermore, plant height was recorded to be increased by the combined application of enriched biochar(s) and DAP, and the maximum value was observed at $100 \%$ RDP, however, no significant difference was found between 50\% RDP and 100\% RDP for both biochar types. In the case of number of primary branches per plant ${ }^{-1}$ (Table 3), the results revealed that no significant difference was recorded between the biochar types. Enriched biochar has improved the number of primary branches when compared with 100\% RDP. Similarly, upon the combined application of enriched biochar(s) with DAP, the number of primary branches were increased and the maximum value was recorded at $100 \%$ RDP for both $\mathrm{PEB}_{1}$ and $\mathrm{PEB}_{2}$, however, statistically no difference was recorded between $50 \%$ RDP and $100 \%$ RDP with both $\mathrm{PEB}_{1}$ and $\mathrm{PEB}_{2}$.

In the case of shoot length, $\mathrm{PEB}_{1}$ and $\mathrm{PEB}_{2}$ have significantly increased shoot length $(\mathrm{cm})$ at $0 \%$ RDP as compared to the control. Shoot length was increased with increasing P dose (25\% RDP) and, it was found highest at 50\% RDP for both $\mathrm{PEB}_{1}$ and $\mathrm{PEB}_{2}$. No significant difference was recorded in between $\mathrm{PEB}_{1}$ and $\mathrm{PEB}_{2}$. Furthermore, shoot length was not significantly increased at $100 \% \mathrm{RDP}$ for both $\mathrm{PEB}_{1}$ and $\mathrm{PEB}_{2}$ as compared to $50 \%$ RDP. A similar trend was observed in the case of root length $(\mathrm{cm})$ as shown in (Table 3$)$. Both $\mathrm{PEB}_{1}$ and $\mathrm{PEB}_{2}$ have significantly improved root length $(\mathrm{cm})$ at $50 \%$ RDP as compared to the control as well as rest of the treatments. In terms of shoot fresh weight (Table 3), a significant increase was recorded for both $\mathrm{PEB}_{1}$ and $\mathrm{PEB}_{2}$ as compared to the control $(0 \%$ RDP). It was also found that shoot fresh weight was increased with the increase in RDP (25\% RDP) for both types of biochar, and the highest value for shoot fresh weight was recorded at 50\% RDP. Further rise in $\mathrm{P}$ dose did not show any significant improvement as compared to 50\% RDP with both $\mathrm{PEB}_{1}$ and $\mathrm{PEB}_{2}$. A similar observation was recorded in the case of root fresh weight as shown in the significant improvement was recorded at 50\% RDP for both $\mathrm{PEB}_{1}$ and $\mathrm{PEB}_{2}$, whereas $\mathrm{PEB}_{1}$ and $\mathrm{PEB}_{2}$ with $100 \%$ RDP have a similar impact on root fresh weight as compared to $100 \%$ RDP alone. Similarly, shoot dry weight and root dry weight were also recorded highest for $50 \%$ RDP for both biochar types while no significant difference was recorded in between biochar types as shown in Table 3 .

\subsubsection{Nodulation}

P-enriched biochar(s), both $\mathrm{PEB}_{1}$ and $\mathrm{PEB}_{2}$, significantly increased the number of nodules per plant $^{-1}$ as compared to the treatment where $100 \%$ RDP was applied, as shown in (Figure 1). Similarly, the number of nodules were significantly increased with the increase in RDP (25\% RDP) with the highest value at 50\% RDP, however, further increase in RDP (100\% RDP) with $\mathrm{PEB}_{1}$ and $\mathrm{PEB}_{2}$ did not yield any significant increase as compared to $50 \%$ RDP with both $\mathrm{PEB}_{1}$ and $\mathrm{PEB}_{2}$. Furthermore, no significant difference was recorded between biochar types, i.e., $\mathrm{PEB}_{1}$ and $\mathrm{PEB}_{2}$.

The nodule weight was significantly improved upon the addition of biochar $\left(\mathrm{PEB}_{1}\right.$ and $\left.\mathrm{PEB}_{2}\right)$ at $0 \%$ RDP (Figure 1). The highest value for nodule weight was recorded at 50\% RDP with both $\mathrm{PEB}_{1}$ and $\mathrm{PEB}_{2}$. Further increase in RDP (100\% RDP) with both $\mathrm{PEB}_{1}$ and $\mathrm{PEB}_{2}$ has not improved nodule weight as compared to $50 \%$ RDP. No significant difference was recorded in between biochar types. 
Table 3. Effect of the combined application of p-enriched biochars (both $\mathrm{PEB}_{1}$ and $\mathrm{PEB}_{2}$ ) and split dose of mineral $\mathrm{P}$ fertilizer on growth (mean values \pm standard deviation) of chickpea.

\begin{tabular}{|c|c|c|c|c|c|c|c|c|}
\hline \multirow{3}{*}{ Treatment } & \multirow{3}{*}{ Plant Height (cm) } & \multirow{3}{*}{$\begin{array}{l}\text { No. of Primary } \\
\text { Branches }\end{array}$} & \multicolumn{2}{|c|}{ Length (cm) } & \multicolumn{4}{|c|}{ Weight (g) } \\
\hline & & & \multirow{2}{*}{ Root } & \multirow{2}{*}{ Shoot } & \multicolumn{2}{|c|}{ Fresh } & \multicolumn{2}{|c|}{ Dry } \\
\hline & & & & & Root & Shoot & Root & Shoot \\
\hline $0 \% \mathrm{RDP}$ & $21.60 \pm 0.25^{g}$ & $4 \pm 0.04^{d}$ & $12.33 \pm 0.49^{f}$ & $23.38 \pm 0.32 \mathrm{~g}$ & $2.63 \pm 0.07 \mathrm{~g}$ & $12.88 \pm 0.05^{g}$ & $1.05 \pm 0.03^{h}$ & $5.13 \pm 0.10^{g}$ \\
\hline $25 \%$ RDP & $23.31 \pm 0.35^{\mathrm{f}}$ & $4 \pm 0.13^{\mathrm{cd}}$ & $14.75 \pm 0.10^{\mathrm{e}}$ & $25.73 \pm 0.20^{f}$ & $3.56 \pm 0.43^{f}$ & $15.10 \pm 0.08^{f}$ & $1.43 \pm 0.17^{g}$ & $6.13 \pm 0.07^{f}$ \\
\hline $50 \%$ RDP & $27.36 \pm 0.46^{\mathrm{e}}$ & $5 \pm 0.14^{\mathrm{cd}}$ & $18.20 \pm 0.10^{d}$ & $29.50 \pm 0.45^{\mathrm{e}}$ & $4.50 \pm 0.31^{\mathrm{e}}$ & $18.59 \pm 0.33^{\mathrm{e}}$ & $1.80 \pm 0.12^{\mathrm{f}}$ & $7.47 \pm 0.11^{\mathrm{e}}$ \\
\hline $100 \%$ RDP & $29.80 \pm 0.10^{d}$ & $5 \pm 0.03^{c}$ & $20.57 \pm 0.49^{c}$ & $32.36 \pm 0.45^{\mathrm{d}}$ & $5.22 \pm 0.24^{\mathrm{e}}$ & $21.61 \pm 0.41^{\mathrm{d}}$ & $2.61 \pm 0.12^{\mathrm{e}}$ & $8.61 \pm 0.15^{d}$ \\
\hline $0 \% \mathrm{RDP}+\mathrm{PEB}_{1}$ & $33.33 \pm 0.49^{c}$ & $6 \pm 0.16^{b}$ & $21.10 \pm 0.10^{c}$ & $33.38 \pm 0.37^{c}$ & $6.10 \pm 0.07^{d}$ & $24.11 \pm 0.08^{c}$ & $3.05 \pm 0.03^{d}$ & $9.65 \pm 0.03^{c}$ \\
\hline $0 \% \mathrm{RDP}+\mathrm{PEB}_{2}$ & $33.43 \pm 0.40^{\mathrm{c}}$ & $6 \pm 0.40^{b}$ & $21.18 \pm 0.20^{c}$ & $33.39 \pm 0.33^{c}$ & $6.06 \pm 0.05^{\mathrm{d}}$ & $23.91 \pm 0.07^{c}$ & $3.03 \pm 0.02^{d}$ & $9.57 \pm 0.11^{\mathrm{c}}$ \\
\hline $25 \% \mathrm{RDP}+\mathrm{PEB}_{1}$ & $37.67 \pm 0.20^{b}$ & $7 \pm 0.46^{a}$ & $23.20 \pm 0.20^{b}$ & $39.47 \pm 0.25^{b}$ & $7.47 \pm 0.44^{c}$ & $26.26 \pm 0.31^{b}$ & $3.74 \pm 0.22^{c}$ & $10.51 \pm 0.12^{b}$ \\
\hline $50 \% \mathrm{RDP}+\mathrm{PEB}_{1}$ & $42.36 \pm 0.46^{\mathrm{a}}$ & $8 \pm 0.53^{a}$ & $27.61 \pm 0.11^{\mathrm{a}}$ & $44.66 \pm 0.15^{\mathrm{a}}$ & $9.94 \pm 0.38^{a}$ & $32.62 \pm 0.47^{\mathrm{a}}$ & $4.63 \pm 0.16^{a b}$ & $12.71 \pm 0.39^{\mathrm{a}}$ \\
\hline $100 \%$ RDP + $\mathrm{PEB}_{1}$ & $42.59 \pm 0.51^{\mathrm{a}}$ & $8 \pm 0.17^{a}$ & $27.20 \pm 0.19^{a}$ & $44.56 \pm 0.38^{a}$ & $9.16 \pm 0.16^{b}$ & $32.64 \pm 0.28^{a}$ & $4.57 \pm 0.08^{b}$ & $12.35 \pm 0.55^{\mathrm{a}}$ \\
\hline $25 \% \mathrm{RDP}+\mathrm{PEB}_{2}$ & $37.30 \pm 0.26^{b}$ & $7 \pm 0.28^{a}$ & $23.21 \pm 0.28^{b}$ & $39.61 \pm 0.29^{b}$ & $7.46 \pm 0.21^{c}$ & $25.38 \pm 0.57^{b}$ & $3.73 \pm 0.10^{c}$ & $10.39 \pm 0.13^{b}$ \\
\hline $50 \% \mathrm{RDP}+\mathrm{PEB}_{2}$ & $42.23 \pm 0.15^{\mathrm{a}}$ & $8 \pm 0.22^{a}$ & $27.34 \pm 0.40^{\mathrm{a}}$ & $44.63 \pm 0.20^{\mathrm{a}}$ & $9.84 \pm 0.13 \mathrm{ab}$ & $33.17 \pm 0.27^{\mathrm{a}}$ & $4.92 \pm 0.06^{\mathrm{a}}$ & $12.27 \pm 0.11^{\mathrm{a}}$ \\
\hline $100 \% \mathrm{RDP}+\mathrm{PEB}_{2}$ & $42.58 \pm 0.36^{\mathrm{a}}$ & $8 \pm 0.21^{a}$ & $27.21 \pm 0.28^{a}$ & $44.61 \pm 0.29^{\mathrm{a}}$ & $9.17 \pm 0.06 \mathrm{~b}$ & $32.58 \pm 0.37^{\mathrm{a}}$ & $4.59 \pm 0.03^{a b}$ & $12.44 \pm 0.28^{a}$ \\
\hline
\end{tabular}

Mean values having different letters (in superscript) are significantly different from one another at a level of significance $<5 \%$ (Tukey HSD test); RDP, recommended dose of $\mathrm{P}_{\text {; }} \mathrm{PEB}_{1}$, biochar enriched through hot method; PEB2, biochar enriched through cold method. 


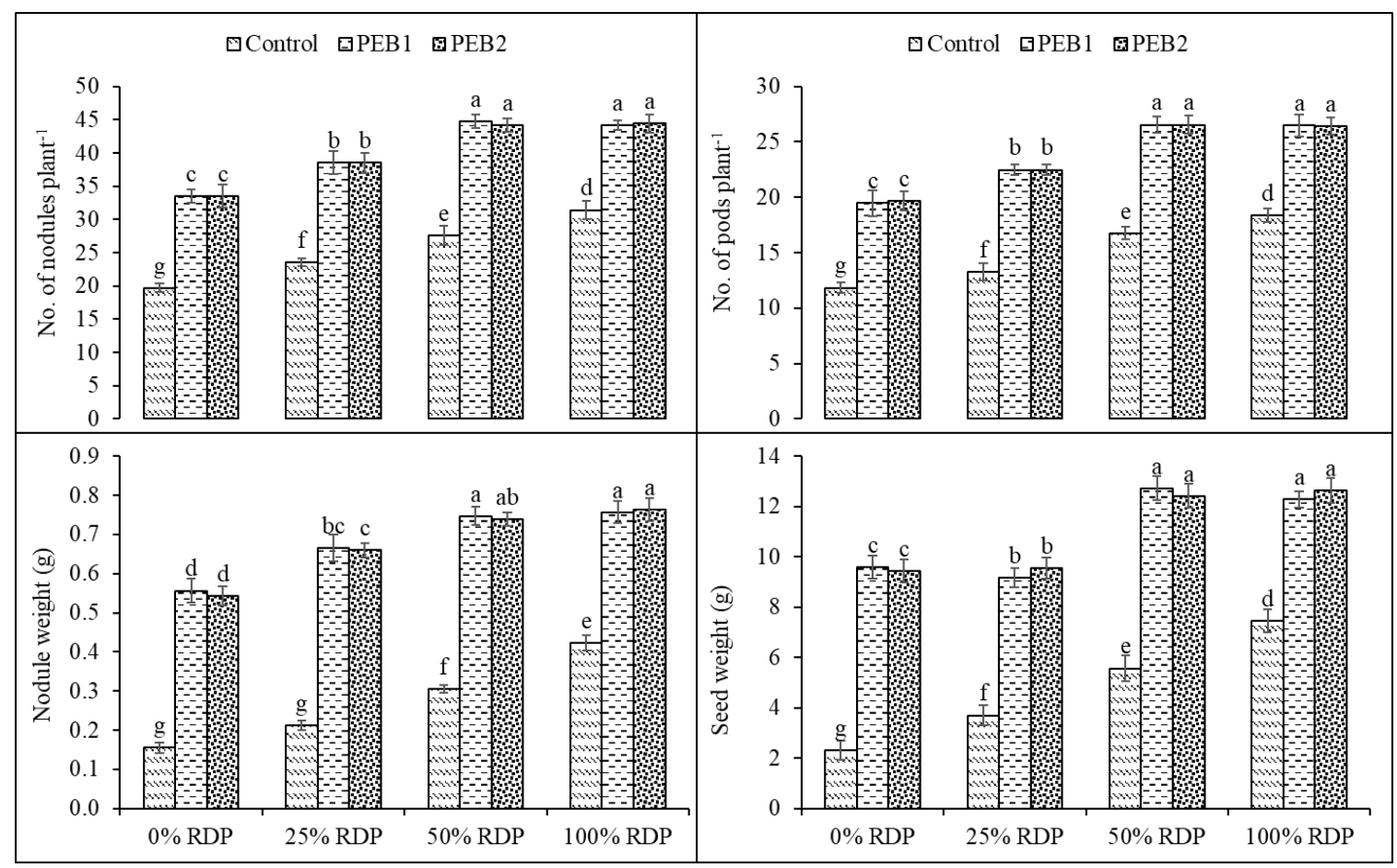

Figure 1. Effect of the combined application of p-enriched biochar and the split dose of recommended $\mathrm{P}$ on the number of nodules per plant ${ }^{-1}$, nodule weight $(\mathrm{g})$, number of pods per plant ${ }^{-1}$ and seed weight (g); mean values are represented by columns whereas the standard error (S.E.) is represented by error bars $(n=3)$; columns having different letters are significantly different from one another at a level of significance $<5 \%$ (Tukey HSD test); $\mathrm{PEB}_{1}$, biochar enriched through the hot method; $\mathrm{PEB}_{2}$ biochar enriched through the cold method; RDP, recommended dose of phosphorus.

\subsubsection{Yield}

PEB1 and $\mathrm{PEB}_{2}$ at $0 \%$ RDP have significantly improved the number of pods as compared to $100 \%$ RDP. A significant increase in the number of pods was recorded for both $\mathrm{PEB}_{1}$ and $\mathrm{PEB}_{2}$ with $50 \% \mathrm{RDP}$ as compared to all other treatments as shown in (Figure 1). Furthermore, $\mathrm{PEB}_{1}$ and $\mathrm{PEB}_{2}$ with 100\% RDP did not show significant improvement as compared to $50 \%$ RDP with $\mathrm{PEB}_{1}$ and $\mathrm{PEB}_{2}$ A similar trend was observed in the case of seed weight $(\mathrm{g})$. It was recorded as the highest for both $\mathrm{PEB}_{1}$ and $\mathrm{PEB}_{2}$ at $50 \% \mathrm{RDP}$ (Figure 1).

\subsection{Impact of P-Enriched Biochar on Physiological Parameters}

The data for photosynthetic rate, transpiration rate, chlorophyll contents and stomatal conductance are given in (Table 4). The results revealed that crop physiological parameters were significantly improved in the treatments where p-enriched biochar was applied without RDP as compared to the control. Similarly, a significant improvement was recorded in terms of physiological parameters in the case of the combined application of p-enriched biochar and split doses of $\mathrm{P}$ up to $50 \%$ RDP, however, further increase in RDP did not show any significant difference when compared to 50\% RDP for both $\mathrm{PEB}_{1}$ and $\mathrm{PEB}_{2}$. Furthermore, both biochar types did not yield significant difference in terms of crop physiological parameters.

\subsection{Impact of P-Enriched Biochar on Chemical Parameters}

The application of $\mathrm{PEB}_{1}$ and $\mathrm{PEB}_{2}$ increased the shoot $\mathrm{P}$ contents at $0 \% \mathrm{RDP}$ as compared to the control. The highest value for shoot $\mathrm{P}$ was recorded at $50 \% \mathrm{RDP}$ for both $\mathrm{PEB}_{1}$ and $\mathrm{PEB}_{2}$, and further increase in RDP $\left(100 \%\right.$ RDP) with both $\mathrm{PEB}_{1}$ and $\mathrm{PEB}_{2}$ did not yield any significant difference. Similarly, no significant difference was recorded in between biochar types. A similar trend was observed in 
the case of shoot nitrogen $(\mathrm{N})$ contents. It was found that the application of p-enriched biochar(s) significantly improved shoot $\mathrm{N}$ contents at $0 \%$ RDP as compared to the treatments where $100 \%$ RDP was applied alone. The highest shoot $\mathrm{N}$ contents were recorded at 50\% RDP for both $\mathrm{PEB}_{1}$ and $\mathrm{PEB}_{2}$. Further increase in RDP did not yield any significance difference as compared to 50\% RDP with both $\mathrm{PEB}_{1}$ and $\mathrm{PEB}_{2}$ (Table 4).

\subsection{Impact of P-Enriched Biochar on Post-Harvest Soil Characters}

The results showed the highest $\mathrm{P}$ contents for both $\mathrm{PEB}_{1}$ and $\mathrm{PEB}_{2}$ with $100 \% \mathrm{RDP}$, however, no statistical difference was recorded between 50\% RDP and 100\% RDP for both biochar types (Table 5). Similarly, both $\mathrm{PEB}_{1}$ and $\mathrm{PEB}_{2}$ with $0 \%$ RDP significantly improved the soil extractable $\mathrm{P}$ as compared to $0 \%$ RDP, 25\% RDP, 50\% RDP and 100\% RDP. Both biochar types yield similar response.

Both $\mathrm{PEB}_{1}$ and $\mathrm{PEB}_{2}$ with $0 \%$ RDP significantly improved the soil organic matter as compared to $0 \%$ RDP, 25\% RDP, 50\% RDP and 100\% RDP. However, no significant difference was recorded when both $\mathrm{PEB}_{1}$ and $\mathrm{PEB}_{2}$ with $0 \%$ RDP were compared with $\mathrm{PEB}_{1}+25 \% \mathrm{RDP}, \mathrm{PEB}_{1}+50 \% \mathrm{RDP}$, $\mathrm{PEB}_{1}+100 \%$ RDP, $\mathrm{PEB}_{2}+25 \%$ RDP, $\mathrm{PEB}_{2}+50 \%$ RDP and $\mathrm{PEB}_{2+} 100 \%$ RDP. Both biochar types showed similar results and did not differ significantly from one another (Table 5).

For both $\mathrm{PEB}_{1}$ and $\mathrm{PEB}_{2}$, the total $\mathrm{N}$ contents of post-harvest soil was significantly improved where p-enriched biochar was used as compared to the control (Table 5). With the addition of split doses of $\mathrm{P}$, the total soil $\mathrm{N}$ was increased up to 50\% RDP, however, further addition in RDP (100\% RDP) for both $\mathrm{PEB}_{1}$ and $\mathrm{PEB}_{2}$ did not yield any significant difference when compared with 50\% RDP.

An increase in the soil EC was recorded for the treatments where both $\mathrm{PEB}_{1}$ and $\mathrm{PEB}_{2}$ were applied with $0 \%$ RDP as compared to control (Table 5). Further increase in soil EC was recorded for the treatments where both $\mathrm{PEB}_{1}$ and $\mathrm{PEB}_{2}$ were applied with mineral $\mathrm{P}$ fertilizer, with the highest value recorded at $100 \%$ RDP. Additionally, both biochar types $\left(\mathrm{PEB}_{1}\right.$ and $\left.\mathrm{PEB}_{2}\right)$ revealed the same effects on soil EC and did not show any significant difference.

Soil $\mathrm{pH}$ was found to be highest at the $0 \%$ RDP when compared with the treatments where the combined application of DAP and biochar was done as shown in (Table 5). pH was slightly decreased upon the addition of both $\mathrm{PEB}_{1}$ and $\mathrm{PEB}_{2}$ as compared to $\%$ RDP, 25\% RDP, 50\% RDP and $100 \%$ RDP. Both biochar types $\left(\mathrm{PEB}_{1}\right.$ and $\left.\mathrm{PEB}_{2}\right)$ showed the same results, as they do not have any a significant difference in the case of $\mathrm{pH}$ of post-harvest soil. 
Table 4. Effect of the combined application of p-enriched biochars (both $\mathrm{PEB}_{1}$ and $\mathrm{PEB}_{2}$ ) and a split dose of mineral $\mathrm{P}$ fertilizer on crop physiological and chemical parameters (mean values \pm standard deviation).

\begin{tabular}{|c|c|c|c|c|c|c|}
\hline \multirow[b]{2}{*}{ Treatment } & \multicolumn{4}{|c|}{ Physiological Parameters } & \multicolumn{2}{|c|}{ Chemical Parameters } \\
\hline & 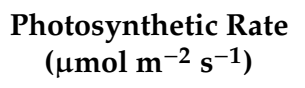 & 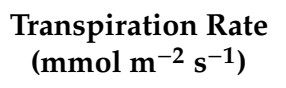 & $\begin{array}{l}\text { Chlorophyll Contents } \\
\left(\mathrm{mmol} \mathrm{cm}-2 \mathrm{~s}^{-1}\right)\end{array}$ & $\begin{array}{l}\text { Stomatal Conductance } \\
\qquad\left(\mu \mathrm{Mol} \mathrm{m}^{-2} \mathrm{~s}^{-1}\right)\end{array}$ & Shoot Nitrogen (\%) & $\begin{array}{c}\text { Shoot Phosphorus } \\
(\%)\end{array}$ \\
\hline $0 \% \mathrm{RDP}$ & $30.43 \pm 0.41 \mathrm{~g}$ & $5.13 \pm 0.04 \mathrm{e}^{\mathrm{e}}$ & $1.34 \pm 0.04^{\mathrm{f}}$ & $220 \pm 0.94 \mathrm{~g}$ & $0.53 \pm 0.03 \mathrm{~g}$ & $0.65 \pm 0.03^{f}$ \\
\hline $25 \%$ RDP & $31.88 \pm 0.61^{\mathrm{f}}$ & $5.24 \pm 0.03^{\mathrm{e}}$ & $1.37 \pm 0.02$ ef & $227 \pm 0.90^{f}$ & $0.64 \pm 0.04^{f}$ & $0.84 \pm 0.03^{\mathrm{e}}$ \\
\hline $50 \%$ RDP & $34.22 \pm 0.30^{\mathrm{e}}$ & $5.77 \pm 0.10^{d}$ & $1.45 \pm 0.04 \mathrm{de}$ & $236 \pm 0.75^{\mathrm{e}}$ & $0.75 \pm 0.03^{\mathrm{e}}$ & $1.26 \pm 0.02^{\mathrm{d}}$ \\
\hline $100 \%$ RDP & $38.54 \pm 0.34^{d}$ & $6.16 \pm 0.13^{c}$ & $1.55 \pm 0.03^{\mathrm{d}}$ & $241 \pm 0.88^{\mathrm{d}}$ & $0.85 \pm 0.02^{d}$ & $1.45 \pm 0.04^{\mathrm{c}}$ \\
\hline $0 \% \mathrm{RDP}+\mathrm{PEB}_{1}$ & $41.15 \pm 0.26^{c}$ & $7.16 \pm 0.03^{b}$ & $2.35 \pm 0.03^{c}$ & $258 \pm 0.76^{c}$ & $0.95 \pm 0.02^{c}$ & $1.65 \pm 0.04^{b}$ \\
\hline $0 \% \mathrm{RDP}+\mathrm{PEB}_{2}$ & $41.21 \pm 0.59 \mathrm{bc}$ & $7.12 \pm 0.10^{b}$ & $2.37 \pm 0.02^{\mathrm{c}}$ & $258 \pm 1.4^{\mathrm{c}}$ & $0.96 \pm 0.03 \mathrm{bc}$ & $1.64 \pm 0.03^{b}$ \\
\hline $25 \% \mathrm{RDP}+\mathrm{PEB}_{1}$ & $42.57 \pm 0.28^{b}$ & $7.32 \pm 0.05^{b}$ & $3.05 \pm 0.03^{b}$ & $264 \pm 0.33^{b}$ & $1.05 \pm 0.03^{b}$ & $1.73 \pm 0.02^{b}$ \\
\hline $50 \%$ RDP + $\mathrm{PEB}_{1}$ & $44.34 \pm 0.37^{a}$ & $7.64 \pm 0.04^{\mathrm{a}}$ & $3.34 \pm 0.04^{\mathrm{a}}$ & $276 \pm 1.02^{a}$ & $1.36 \pm 0.03^{\mathrm{a}}$ & $2.04 \pm 0.03^{a}$ \\
\hline $100 \%$ RDP + $\mathrm{PEB}_{1}$ & $44.87 \pm 0.67^{\mathrm{a}}$ & $7.76 \pm 0.06^{\mathrm{a}}$ & $3.38 \pm 0.05^{\mathrm{a}}$ & $277 \pm 1.81^{\mathrm{a}}$ & $1.34 \pm 0.03^{a}$ & $2.05 \pm 0.03^{\mathrm{a}}$ \\
\hline $25 \% \mathrm{RDP}+\mathrm{PEB}_{2}$ & $42.40 \pm 0.38^{b c}$ & $7.32 \pm 0.08^{b}$ & $3.06 \pm 0.02^{b}$ & $264 \pm 0.95^{b}$ & $1.04 \pm 0.03 \mathrm{bc}$ & $1.72 \pm 0.02^{b}$ \\
\hline $50 \% \mathrm{RDP}+\mathrm{PEB}_{2}$ & $44.10 \pm 0.10^{\mathrm{a}}$ & $7.63 \pm 0.03^{\mathrm{a}}$ & $3.33 \pm 0.03^{\mathrm{a}}$ & $275 \pm 040^{a}$ & $1.36 \pm 0.02^{\mathrm{a}}$ & $2.05 \pm 0.03^{\mathrm{a}}$ \\
\hline $100 \% \mathrm{RDP}+\mathrm{PEB}_{2}$ & $45.09 \pm 0.88^{a}$ & $7.72 \pm 0.08^{a}$ & $3.43 \pm 0.04^{\mathrm{a}}$ & $277 \pm 2.08^{a}$ & $1.34 \pm 0.03^{a}$ & $2.06 \pm 0.03^{\mathrm{a}}$ \\
\hline
\end{tabular}

Mean values having different letters (in superscript) are significantly different from one another at a level of significance $<5 \%$ (Tukey HSD test); RDP, recommended dose of P; PEB 1 , biochar enriched through hot method; PEB2, biochar enriched through cold method. 
Table 5. Effect of the combined application of p-enriched biochars (both $\mathrm{PEB}_{1}$ and $\mathrm{PEB}_{2}$ ) and a split dose of mineral $\mathrm{P}$ fertilizer on selected properties (mean values \pm standard deviation) of post-harvest soil.

\begin{tabular}{|c|c|c|c|c|c|}
\hline Treatments & $\begin{array}{c}\text { Extractable Phosphorus } \\
\left(\mathrm{mgkg}^{-1}\right)\end{array}$ & Nitrogen $(\%)$ & Organic Matter (\%) & $\mathrm{EC}\left(\mathrm{dSm}^{-1}\right)$ & $\mathrm{pH}$ \\
\hline $0 \% \mathrm{RDP}$ & $4.07 \pm 0.05^{\mathrm{f}}$ & $0.22 \pm 0.03^{\mathrm{e}}$ & $0.53 \pm 0.10^{b}$ & $0.95 \pm 0.02^{h}$ & $8.17 \pm 0.09^{a}$ \\
\hline $25 \%$ RDP & $4.55 \pm 0.28^{\text {ef }}$ & $0.28 \pm 0.02^{\mathrm{e}}$ & $0.52 \pm 0.07^{b}$ & $1.25 \pm 0.04^{g}$ & $8.13 \pm 0.19^{a b}$ \\
\hline $50 \%$ RDP & $5.15 \pm 0.12$ de & $0.79 \pm 0.05^{\mathrm{d}}$ & $0.58 \pm 0.02^{b}$ & $1.44 \pm 0.02^{\mathrm{f}}$ & $8.14 \pm 0.40^{a}$ \\
\hline $100 \%$ RDP & $5.43 \pm 0.16^{d}$ & $0.89 \pm 0.04^{\mathrm{cd}}$ & $0.56 \pm 0.03^{b}$ & $1.64 \pm 0.03^{\mathrm{e}}$ & $8.14 \pm 0.18^{a}$ \\
\hline $0 \% \mathrm{RDP}+\mathrm{PEB}_{1}$ & $7.12 \pm 0.04^{c}$ & $1.00 \pm 0.05^{b c}$ & $0.94 \pm 0.03^{a}$ & $1.84 \pm 0.03^{\mathrm{d}}$ & $7.98 \pm 0.04^{b c}$ \\
\hline $0 \% \mathrm{RDP}+\mathrm{PEB}_{2}$ & $7.27 \pm 0.18^{c}$ & $0.99 \pm 0.04^{b c}$ & $0.93 \pm 0.02^{a}$ & $1.85 \pm 0.02^{\mathrm{d}}$ & $7.97 \pm 0.06^{\mathrm{cd}}$ \\
\hline $25 \% \mathrm{RDP}+\mathrm{PEB}_{1}$ & $8.36 \pm 0.16^{b}$ & $1.10 \pm 0.04^{b}$ & $0.94 \pm 0.02^{a}$ & $2.24 \pm 0.03^{c}$ & $7.97 \pm 0.09 \mathrm{~cd}$ \\
\hline $50 \% \mathrm{RDP}+\mathrm{PEB}_{1}$ & $9.35 \pm 0.22^{a}$ & $1.99 \pm 0.04^{\mathrm{a}}$ & $0.96 \pm 0.02^{a}$ & $2.85 \pm 0.02^{b}$ & $7.82 \pm 0.06^{d}$ \\
\hline $100 \% \mathrm{RDP}+\mathrm{PEB}_{1}$ & $9.43 \pm 0.41^{a}$ & $2.08 \pm 0.05^{a}$ & $0.95 \pm 0.03^{a}$ & $3.15 \pm 0.04^{\mathrm{a}}$ & $7.87 \pm 0.06^{\mathrm{cd}}$ \\
\hline $25 \% \mathrm{RDP}+\mathrm{PEB}_{2}$ & $8.28 \pm 0.14^{b}$ & $1.09 \pm 0.04^{b}$ & $0.97 \pm 0.01^{\mathrm{a}}$ & $2.25 \pm 0.03^{c}$ & $7.97 \pm 0.09 \mathrm{~cd}$ \\
\hline $50 \% \mathrm{RDP}+\mathrm{PEB}_{2}$ & $9.34 \pm 0.48^{a}$ & $2.01 \pm 0.04^{a}$ & $0.96 \pm 0.03^{a}$ & $2.86 \pm 0.04^{b}$ & $7.97 \pm 0.06^{c d}$ \\
\hline $100 \%$ RDP $+\mathrm{PEB}_{2}$ & $9.53 \pm 0.42^{\mathrm{a}}$ & $2.07 \pm 0.03^{a}$ & $0.95 \pm 0.04^{\mathrm{a}}$ & $3.17 \pm 0.01^{\mathrm{a}}$ & $7.97 \pm 0.06^{\mathrm{cd}}$ \\
\hline
\end{tabular}

Mean values having different letters (in superscript) are significantly different from one another at level of significance $<5 \%$ (Tukey HSD test); RDP, recommended dose of $\mathrm{P}$; PEB 1 , biochar enriched through hot method; PEB2, biochar enriched through cold method. 


\section{Discussion}

In the present study, the soil used for both the incubation and pot study contain a very low level of extractable phosphorus (below $5 \mathrm{mg} \mathrm{kg}^{-1}$ ). With the application of p-enriched biochar(s), produced from wheat straw at low pyrolytic temperature $\left(350-400{ }^{\circ} \mathrm{C}\right)$, an improvement in soil extractable $\mathrm{P}$ was recorded after both 15 and 30 days of incubation. The increase in soil $\mathrm{P}$ was probably due to the presence of $\mathrm{P}$ in biochar as pyrolysis would result in the retention of $\mathrm{P}$ contents within biochar [36] which would be present in the plant available form [37]. Secondly, the increase in P may be due to the reduction of $P$ fixation in the soil as biochar can alter the adsorption and desorption equilibrium in soil [38,39]. Furthermore, with the incorporation of $\mathrm{P}$ source (DAP) into biochar, an increase in soil $\mathrm{P}$ was observed. The highest phosphorus contents were recorded for the treatments where DAP was incorporated into biochar after both 15 and 30 days of incubation (Tables 1 and 2). This is probably due to the potential of biochar to enhance the availability of nutrients [40,41]. El Sharkawi et al. [42] also found better results for biochar-based ammonium phosphate slow release fertilizer as compared to the direct application of mineral fertilizer. Furthermore, available P was decreased where DAP alone (100:0) was applied after both 15 and 30 days of incubation. This decrease suggested that $P$ got fixed (the solubility of $P$ was reduced due to the formation of calcium phosphates in soil containing high amounts of $\mathrm{Ca}^{2+}[5]$ by $\mathrm{P}$ complexing metallic ions (Ca and $\mathrm{Mg}$ ) as the experimental soil was of calcareous nature.

In case of the soil total $\mathrm{N}$, the application of biochar alone did not significantly improve $\mathrm{N}$ contents when compared with the control after both 15 and 30 days of incubation (Tables 1 and 2). This finding is in line with the previous study that no change was recorded for soil total $\mathrm{N}$ upon the addition of biochar as compared to the control [43]. This might be due to the formation of heterocyclic $\mathrm{N}$ compounds (cannot be easily solubilized) during pyrolysis, thus reducing the available $\mathrm{N}$ fraction in the biochar [44]. Furthermore, with the impregnation of DAP into biochar, the soil total $\mathrm{N}$ was recorded to be increased as compared to the control, however, the values recorded for $\mathrm{N}$ were higher after 30 days of incubation when compared with the values obtained after 15 days of incubation. This increase is probably due to the potential of biochar to reversibly hold the nutrients [45], and the higher values after 30 days of incubation were due to the ability of biochar to serve as slow-release fertilizer [46,47].

The post-harvest soil showed greater values for soil extractable $\mathrm{P}$ for the treatments where phosphorus-enriched biochar was used. This is because the enrichment of phosphorus (DAP) with biochar renders it to a low release fertilizer. Moreover, biochar helps to capture P complexing metallic ions, thus reducing the chances of $\mathrm{P}$ to become fixed. Mendes et al. [48] confirmed the presence of metal complexing organic acids secreted by certain microbes. In addition, biochar has the ability to alter the equilibrium of adsorption and desorption $\mathrm{P}$, thus effecting the $\mathrm{P}$ dynamic in the soil [38,39]. The availability of $\mathrm{P}$ after crop harvest was not increased in this case, where DAP is applied directly (without enrichment). Same results were also investigated in previous studies that about $80-90 \%$ of phosphorus were lost when applied in mineral fertilizer form [49]. Similarly, soil total N contents were found to be higher for the treatments where p-enriched biochar was used (Table 5). This increase might be due to the attribute of biochar to reduce $\mathrm{N}$ losses from farmlands as it was reported in the previous studies that the $\mathrm{NO}_{3}{ }^{-}$leaching was reduced up to $75 \%$ upon the addition of biochar at a rate of $10 \mathrm{tha}^{-1}$ [50]. Secondly, the test crop was a legume, thus it has added nitrogen to the $\mathrm{N}$ pool of post-harvest soil through biological nitrogen fixation [51].

The organic matter of soil was assessed for incubated soil as well as post-harvest soil, it is obvious that biochar will improve soil organic matter as biochar is a product that is obtained through burning biomass with a little or no oxygen, which becomes a carbon-rich soil amendment. Similarly, results were also reported that biochar significantly increased soil organic carbon when applied as soil amendment [52]. Organic matter in the post-harvest soil was also high, probably because of the highly recalcitrant nature of biochar. It was also observed in the previous studies that Biochar is highly recalcitrant and remains in the soil for several hundreds of years if applied as soil amendment [53,54]. Similarly, numerous studies showed that the application of biochar to the soil improves soil organic carbon [24,55]. 
The soil electrical conductivity (EC dS $\mathrm{m}^{-1}$ ) of both incubated soil (Tables 1 and 2) and post-harvest soil (Table 5) tends to increase with the application of biochar. This increase in the EC of soil is due to the release of loosely bound nutrients/elements to the soil solution when biochar is applied. Same results were observed in previous studies that biochar addition has increased soil EC [56,57]. Secondly, the biochar is derived from wheat straw which is rich in K contents (Supplementary Table S2) which might have contributed to increase EC levels of soil [58,59].

Data on the soil $\mathrm{pH}$ were recorded for incubation over 30 days as well as for post-harvest soil. A slight decrease in soil $\mathrm{pH}$ was observed where biochar was applied as compared to the control and the preparation of biochar at low pyrolytic temperature $\left(350-400^{\circ} \mathrm{C}\right)$. At lower pyrolytic temperatures, $\mathrm{pH}$ of biochar would not be as high to interfere with soil $\mathrm{pH}$. With the higher pyrolytic temperature, the acidic functional groups were removed, tending the biochar to be more basic in nature $[60,61]$. The little reduction in $\mathrm{pH}$ was probably due to the release of acidic materials during the disintegration of biochar $[62,63]$. It was found that upon the slow disintegration of biochar in soil, $\mathrm{pH}$ was reduced due to release of carboxylic groups from the biochar [64,65].

Both $\mathrm{PEB}_{1}$ and $\mathrm{PEB}_{2}$ significantly improved the growth of chickpea in combination with $50 \%$ RDP. The improvement in crop growth was probably due to the availability of $P$ throughout the crop stand as biochar is highly recalcitrant in nature. Phosphorus plays a vital role in the growth and development of plants as it was found to have promoted early root development; it is an important part of nucleic acid; it has a crucial role in cell division and in energy transfer [66]. Secondly, the improvement in crop growth might be due to the ability of biochar to improve the physico-chemical and biological properties of soil. In previous studies, it was found that the addition of biochar has improved the nutrient holding capacity of soil [67,68]; the water holding capacity of soil [67]; the water use efficiency of crops [69]; increased the cation exchange capacity of soil [70]; and increased the soil microbial activity [56]. It was found in this study that the enrichment technique (PEB1 and PEB2) did not yield any significant difference in terms of crop growth, however, Pandit et al., [71] demonstrated better crop growth in the case of hot nutrient enrichment. During the hot enrichment, biochar pores become wider and more flexible, which are supposed to increase water and nutrient penetration [72].

This significant impact on root nodulation was probably due to the potential of biochar to influence soil microbial communities. It was found that biochar application can influence microbial communities by increasing soil aeration; nutrient availability; reduction in the concentration of toxic chemicals; and by providing a suitable habitat [73]. Secondly, the incorporation of $\mathrm{P}$ (DAP) with biochar ensured the availability of $P$ in sufficient quantities due to which nodulation was improved as the abundance of $P$ supports the motility of bacteria-necessary for bacterial migration. Poor nodule growth was recorded in P-deficient soils due to the inability of bacteria to infect plant roots [74]. It was found in previous studies that almost $25 \%$ plant $P$ would be distributed to nodule fraction $[75,76]$.

Chickpea yield was recorded as the highest in the treatments where $\mathrm{PEB}_{1}$ and $\mathrm{PEB}_{2}$ were added with 50\% RDP as compared to all other treatments (Figure 1). Since leguminous crops require more $P$ as compared to other crops due to their involvement in biological nitrogen fixation, therefore the yield of chickpea was improved with the addition of p-enriched biochar as the impregnation of P (DAP) with biochar has increased P availability as compared to DAP alone (Table 2). A better yield for chickpea was also recorded in previous studies upon the addition of high dose of P fertilizers [77]. Similarly, Kumar and Sreenivasulu [78] noted a higher number of pods where P application was higher. Gruhn et al. [79] recorded more grain yield in the case of high P fertilizer dose. However, it is not a matter of fact that the impregnation of mineral fertilizer always results in yield increase as it was found that enriched biochar applied at a rate of $1.5 \mathrm{tha}^{-1}$ with and without compost did not show any significant improvements in terms of yield in a pot trial [80].

Crop physiological parameters were significantly improved where p-enriched biochar was used alone as well as in combination with the split doses of mineral P fertilizer (Table 4). The photosynthesis rate was significantly improved where p-enriched biochar was used with 50\% RDP. This improvement might be due to the role of biochar and $\mathrm{P}$ in promoting stomatal conductance (Table 4) which in 
turn resulted in a greater flow of carbon dioxide to the leaf mesophyll cells. In previous studies, high photosynthetic rates were recorded with high $\mathrm{P}$ applications in groundnut [81] and in cluster bean [82]. Similarly, high transpiration rates were recorded upon the application of p-enriched biochar with 50\% RDP, probably due to greater stomatal conductance. Furthermore, the chlorophyll contents were also found to be higher for the treatments where p-enriched biochar was used with $50 \%$ RDP. This was probably due to the effect of enriched biochar on plant nutritional status [83] as the increased uptake of $\mathrm{C}, \mathrm{N}$ and $\mathrm{P}$ was found to have a significant impact on the chlorophyll contents [84]. Similarly, stomatal conductance was improved where p-enriched biochar was used with 50\% RDP, due to two possible reasons. Firstly, stomatal conductance was recorded as higher for the crops grown in high moisture contents [85], since biochar can improve soil moisture retention and plant available water [67], so it has increased stomatal conductance. Secondly, the availability of P in abundance throughout the crop stand has resulted in higher stomatal conductance as it was increased with higher $P$ rates due to its greater role in plant growth and anatomy [86-88].

The chemical parameters were also significantly improved by the p-enriched biochar (Table 5). The increase in shoot $\mathrm{P}$ contents might be due to the availability of $\mathrm{P}$ in the soil solution in bulk, and increased biological activity for $\mathrm{P}$ solubilization $[89,90]$. Shoot $\mathrm{N}$ contents were recorded low for the treatments where $\mathrm{P}$ was applied alone $(0 \%, 25 \%, 50 \%$ and $100 \%)$ because $\mathrm{N}$ base dressing was kept low $\left(15 \mathrm{~kg} \mathrm{ha}^{-1}\right)$ keeping in view the potential of chickpea to fix atmospheric nitrogen. Since the experimental soil was of calcareous nature (Supplementary Table S1), it reduced the availability of $P$ where it was applied without p-enriched biochar due to the formation of calcium phosphates [5]. It is well established that phosphorus is required in larger quantities for legumes as it promotes biological nitrogen fixation, the partitioning of photosynthates, biomass production and nodulation [91]. In the case of $\mathrm{P}$ deficiency, the legume growth retards severely which results in a lower number of root nodules, hence lower will be the ability to fix nitrogen apart from overall growth [92]. Shoot $\mathrm{N}$ contents were maximum where p-enriched biochar was applied with 50\% RDP, probably due to the development of a better rooting system which in turn supported biological nitrogen fixation and facilitated the uptake of nitrogen along with other nutrients from soil solution $[93,94]$.

\section{Conclusions}

Based on the incubation experiment, for the formulation of biochar-based P fertilizer, the optimum impregnation ratio for DAP to biochar on a $w / w$ basis is 50:50 as it had showed maximum plant available $P$ contents after 30 days of incubation period. A significant improvement in growth, yield, nodulation and plant physiological and chemical parameters was recorded in the pot trial upon the addition of p-enriched biochar with a 50\% recommended dose of $\mathrm{P}$, however, the enrichment technique, i.e., the hot and cold methods, did not yield any significant difference in both the incubation experiment and pot trial, hence either the cold or hot method can be used for enrichment. Maximum crop growth and yield can be obtained through the incorporation of a mineral P source into biochar with minimum additional $P$ inputs. It can minimize the input costs incurred on fertilizer and can reduce the $\mathrm{P}$ losses from farmlands. Additionally, this approach also partakes the role of recycling phosphorus as bio-waste (contains nutrients including $\mathrm{P}$ ) which is used for the production of biochars. Thus, the incorporation of mineral fertilizer into biochar followed by its soil application is a win-win approach as it can promote crop growth with minimum nutrient input and it can also recycle nutrients. Further research should be conducted to assess the potential of phosphorus-enriched biochar to serve as a P reserve in soil through studying its residual effects as biochar is highly recalcitrant in nature and it can reversibly hold cations for a considerable time span as compared to other organic amendments.

Supplementary Materials: The following are available online at http://www.mdpi.com/2071-1050/12/22/9528/s1, Table S1: Some selected characteristics of soil used in both the incubation experiment and pot trial; Table S2: Some selected characteristics of biochar used for the purpose of enrichment. 
Author Contributions: Conceptualization, M.N. and M.S.E.; methodology, F.W.; software, M.A.B.; validation, M.N., M.A. and J.A.; formal analysis, Z.A.; investigation, M.N.; resources, M.S.A.; data curation, F.W.; writing-original draft preparation, F.W.; M.A.B.; writing—review and editing, M.N.; M.S.E; M.S.A.; visualization, J.A.; supervision, M.N.; project administration, M.N.; funding acquisition, M.S.E. All authors have read and agreed to the published version of the manuscript.

Funding: Researchers Supporting Project number (RSP-2020/193), King Saud University, Riyadh, Saudi Arabia.

Acknowledgments: The authors would like to extend their appreciation to the researchers supporting project number (RSP-2020/193), King Saud University, Riyadh, Saudi Arabia. This research work was conducted with the technical assistance of Soil and Environmental Microbiology Laboratory, Institute of Soil and Environmental Science, University of Agriculture Faisalabad, Pakistan.

Conflicts of Interest: The authors declare no conflict of interest.

\section{References}

1. FAO. The State of Food Security and Nutrition in the World; FAO: Rome, Italy, 2017.

2. Scholz, R.W.; Wellmer, F.W. Approaching a dynamic view on the availability of mineral resources: What we may learn from the case of phosphorus? Glob. Environ. Chang. 2013, 23, 11-27. [CrossRef]

3. Ashley, K.; Cordell, D.; Mavinic, D. A brief history of phosphorus: From the philosopher's stone to nutrient recovery and reuse. Chemosphere 2011, 84, 737-746. [CrossRef] [PubMed]

4. Scavia, D.; Allan, J.; Arend, K.; Bartell, S.; Beletsky, D.; Bosch, N.; Brandt, S.B.; Briland, R.D.; Daloğlu, I.; DePinto, J.V.; et al. Assessing and addressing the re-eutrophication of Lake Erie: Central basin hypoxia. J. Great Lakes Res. 2014, 40, 226-246. [CrossRef]

5. Bell, L.C.; Black, C.A. Transformation of dibasic calcium phosphate di-hydrate and octa-calcium phosphate in slightly acid and alkaline soils. Soil Sci. Soc. Am. J. 2013, 34, 583-587. [CrossRef]

6. Mitran, T.; Mani, P.K. Effect of organic amendments on rice yield trend, phosphorus use efficiency, uptake, and apparent balance in soil under long-term rice-wheat rotation. J. Plant Nutr. 2017, 40, 1312-1322. [CrossRef]

7. Fertiliser Working Party. Phasing-Out the Use of Highly Soluble Phosphorus Fertilisers in an Environmentally Sensitive Areas of South West and Western Australia; Minister of the Environment: Western Australia, Australia, 2007; pp. 5-6.

8. Correll, D.L. The Role of Phosphorus in the Eutrophication of Receiving Waters: A Review. J. Environ. Qual. 1998, 27, 261-266. [CrossRef]

9. Sanders, J.L.; Murphy, L.S.; Noble, A.; Melgar, R.J.; Perkins, J. Improving phosphorus use efficiency with polymer technology. Procedia Eng. 2012, 46, 178-184. [CrossRef]

10. Guelfi, D.R.; Chagas, W.F.T.; Lacerda, J.R.; Chagas, R.M.R.; de Souza, T.L.; Andrade, A.B. Monoammonium phosphate coated with polymers and magnesium for coffee plants. Cienc. Agrotecnol. 2018, 42, 139-147. [CrossRef]

11. Erro, J.; Urrutia, O.; Baigorri, R.; Fuentes, M.; Zamarreño, A.M.; Garcia-Mina, J.M. Incorporation of humic-derived active molecules into compound NPK granulated fertilizers: Main technical difficulties and potential solutions. Chem. Biol. Technol. Agric. 2016, 3, 1-15. [CrossRef]

12. Sikora, L.; Enkiri, N. Efficiency of compost-fertiliser blends compared with fertilizer alone. Soil Sci. 2000, 165, 444-451. [CrossRef]

13. Cornish, P.S. Research directions: Improving plant uptake of soil phosphorus, and reducing dependency on input of phosphorus fertilisers. Crop Past. Sci. 2009, 60, 190-196. [CrossRef]

14. Lehmann, J. Bio-energy in the black. Front. Ecol. Environ. 2007, 5, 381-387. [CrossRef]

15. Chia, C.H.; Munroe, P.; Joseph, S.; Lin, Y. Microscopic characterization of synthetic Terra Preta. Aust. J. Soil Res. 2010, 48, 593-605. [CrossRef]

16. Hilber, I.; Blum, F.; Leifeld, J.; Schmidt, H.P.; Bucheli, T.D. Quantitative determination of PAHs in biochar: A prerequisite to ensure its quality and safe application. J. Agric. Food Chem. 2012, 60, 3042-3050. [CrossRef]

17. Perera, F.P. Environment and cancer: Who are susceptible? Science 1997, 278, 1068-1073. [CrossRef]

18. Gao, Y.; Collins, C.D. Uptake pathways of polycyclic aromatic hydrocarbons in white clover. Environ. Sci. Technol. 2009, 43, 6190-6195. [CrossRef] 
19. Hale, S.E.; Lehmann, J.; Rutherford, D.; Zimmerman, A.R.; Bachmann, R.T.; Shitumbanuma, V.; O’Toole, A.; Sundqvist, K.L.; Arp, H.P.H.; Cornelissen, G. Quantifying the total and bioavailable polycyclic aromatic hydrocarbons and dioxins in biochars. Environ. Sci. Technol. 2012, 46, 2830-2838. [CrossRef]

20. Wang, Z.; Zheng, H.; Luo, Y.; Deng, X.; Herbert, S.; Xing, B. Characterization and influence of biochars on nitrous oxide emission from agricultural soil. Environ. Pollut. 2013, 174, 289-296. [CrossRef]

21. Steiner, C.; Teixeira, W.G.; Lehmann, J.; Nehls, T.; Macêdo, J.L.V.; Blum, W.E.H. Long term effects of manure, charcoal and mineral fertilization on crop production and fertility on a highly weathered Central Amazonian upland soil. Plant Soil 2007, 291, 275-290. [CrossRef]

22. Yamato, M.; Okimori, Y.; Wibowo, I.F.; Anshori, S.; Ogawa, M. Effects of the application of charred bark of Acacia mangium on the yield of maize, cowpea and peanut, and soil chemical properties in South Sumatra, Indonesia. Soil Sci. Plant Nutr. 2006, 52, 489-495. [CrossRef]

23. Schmidt, H.P.; Pandit, B.; Martinsen, V.; Cornelissen, G.; Conte, P.; Kammann, C.I. Fourfold increase in pumpkin yield in response to low-dosage root zone application of urine-enhanced biochar to a fertile tropical soil. Agriculture 2015, 5, 723-741. [CrossRef]

24. Abel, S.; Peters, A.; Trinks, S.; Schonsky, H.; Facklam, M. Impact of biochar and hydrochar addition on water retention and water repellency of sandy soil. Geoderma 2013, 202, 183-191. [CrossRef]

25. Shaaban, M.; Zwieten, L.V.; Bashir, S.; Younas, A.; Núnez-Delgado, A.; Chhajro, M.A.; Kubar, K.A.; Ali, U.; Rana, M.S.; Mehmood, M.A.; et al. A concise review of biochar application to agricultural soils to improve soil conditions and fight pollution. J. Environ. Manag. 2018, 228, 429-440. [CrossRef] [PubMed]

26. Olsen, S.R.; Cole, C.V.; Watanabe, F.S.; Dean, L.A. Estimation of Available Phosphorus in Soils by Extraction with Sodium Bicarbonate; US Department of Agriculture: Washington, DC, USA, 1954.

27. Walkley, A. A critical examination of a rapid method for determining organic carbon in soils: Effect of variations in digestion conditions and of organic soil constituents. Soil Sci. 1947, 63, 251-263. [CrossRef]

28. Keeney, D.R.; Nelson, D.N. Nitrogen-Inorganic Forms. In Methods of Soil Analysis; Page, A.L., Miller, R.H., Keeney, D.R., Eds.; SSSA/ASA: Madison, WI, USA, 1982; pp. 643-698.

29. Leoppert, R.H.; Hallmark, C.T.; Koshy, M.M. Routine procedure for rapid determination of soil carbonates. Soil Sci. Soc. Am. J. 1984, 48, 1030-1033. [CrossRef]

30. Rajkovich, S.; Enders, A.; Hanley, K.; Hyland, C.; Zimmerman, A.R.; Lehmann, J. Corn growth and nitrogen nutrition after additions of biochars with varying properties to a temperate soil. Biol. Fertil. Soils 2012, 48, 271-284. [CrossRef]

31. Wolf, B. The comprehensive system of leaf analysis and its use for diagonosing crop nutrient status. Commun. Soil Sci. Plant Anal. 1982, 13, 1035-1059. [CrossRef]

32. Figueredo, N.A.; Costa, L.M.; Melo, L.C.A.; Siebeneichlerd, E.A.; Tronto, J. Characterization of biochars from different sources and evaluation of release of nutrients and contaminants. Agron. Sci. Mag. 2017, 48, 395-403. [CrossRef]

33. Rashid, A. Mapping Zinc Fertility of Soils Using Indicator Plants and Soils-Analyses. Ph.D. Thesis, University of Hawaii, Honolulu, HI, USA, 1986.

34. Jackson, M.L. Soil Chemical Analysis; Prentice-Hall Inc.: Englewood Cliffs, NJ, USA, 1958; Volume 85, pp. 251-252.

35. Little, T.M.; Hills, F.J. Agricultural Experimentation: Design and Analysis (No. 630.72 L5); Wiley \& Sons: New York, NY, USA, 1978.

36. Morales, M.M.; Comerford, N.; Guerrini, I.A.; Falcaand, N.P.S.; Reeves, J.B. Sorption and desorption of phosphate on biochar and biochar-soil mixtures. Soil Use Manag. 2013, 29, 306-314. [CrossRef]

37. Pan, H.; Eberhardt, T.L. Characterization of fly ash from the gasification of wood and assessment for its application as a soil amendment. Bioresources 2011, 6, 3987-4004.

38. Soinne, H.; Hovi, J.; Tammeorg, P.; Turtola, E. Effect of biochar on phosphorus sorption and clay soil aggregate stability. Geoderma 2014, 219, 162-167. [CrossRef]

39. Gao, S.; Hoffman-Krull, K.; Bidwell, A.L.; DeLuca, T.H. Locally produced wood biochar increases nutrient retention and availability in agricultural soils of the San Juan Islands, USA. Agric. Ecosyst. Environ. 2016, 233, 43-54. [CrossRef]

40. Magrini, K.A.; Czernik, S.; Pilath, H.M.; Evans, R.J.; Ching, P.; Leventhal, J. Biomass derived, carbon sequestering, designed fertilizers. Ann. Environ. Sci. 2009, 3, 217. 
41. Liu, Y.X.; Wu, W.X.; Shi, D.Z.; Zhong, Z.K.; Yang, M. Evaluation of biochar effects on nitrogen retention and leaching in multi-layered soil columns. Water Air Soil Pollut. 2010, 213, 47-55.

42. El Sharkawi, H.M.; Tojo, S.; Chosab, T.; Malhatcamd, F.M.; Youssef, A.M. Biochar-ammonium phosphate as an uncoated-slow release fertilizer in sandy soil. Biomass Bioenerg. 2018, 117, 154-160. [CrossRef]

43. Vaccari, F.P.; Baronti, S.; Lugato, E.; Genesio, L.; Castaldi, S.; Fornasier, F.; Miglietta, F. Biochar as a strategy to sequester carbon and increase yield in durum wheat. Eur. J. Agron. 2011, 34, 231-238. [CrossRef]

44. Knicker, H. "Black nitrogen"-An important fraction in determining the recalcitrance of charcoal. Org. Geochem. 2010, 41, 947-950. [CrossRef]

45. Singh, B.P.; Hatton, B.J.; Singh, B.; Cowie, A.L.; Kathuria, A. Influence of biochars on nitrous oxide emission and nitrogen leaching from two contrasting soils. J. Environ. Qual. 2010, 39, 1224-1235. [CrossRef]

46. Hale, S.E.; Alling, V.; Martinsen, V.; Mulder, J.; Breedveld, G.D.; Cornelissen, G. The sorption and desorption of phosphate-P, ammonium-N and nitrate-N in cacao shell and corn cob biochars. Chemosphere 2013, 91, 1612-1619. [CrossRef]

47. Alling, V.; Hale, S.E.; Martinsen, V.; Mulder, J.; Smebye, A.; Breedveld, G.D.; Cornelissen, G. The role of biochar in retaining nutrients in amended tropical soils. J. Plant Nutr. Soil Sci. 2014, 177, 671-680. [CrossRef]

48. Mendes, D.O.; Zafra, D.L.; Vassilev, N.B.; Silva, I.R.; Ribeiro, J.I.; Costaa, M.D. Biochar enhances Aspergillus niger rock phosphate solubilization by increasing organic acid production and alleviating fluoride toxicity. Appl. Environ. Microbiol. 2014, 80, 3081-3085. [CrossRef] [PubMed]

49. Naderi, M.; Danesh, S. Nano-fertilizers and their roles in sustainable agriculture. Int. J. Agric. Crop Sci. 2013, 5, 2229-2232.

50. Ventura, M.; Sorrenti, G.; Panzacchi, P.; George, E.; Tonon, G. Biochar reduces short-term nitrate leaching from a horizon in an apple orchard. J. Environ. Qual. 2013, 42, 76-82. [CrossRef] [PubMed]

51. Lemke, R.L.; Zhong, Z.; Campbell, C.A.; Zentner, R.P. Can pulse crops play a role in mitigating greenhouse gases from North American agriculture? Agron. J. 2007, 99, 1719-1725. [CrossRef]

52. Biederman, L.A.; Harpole, W.S. Biochar and its effects on plant productivity and nutrient cycling: A meta-analysis. Glob. Chang. Biol. Bioenergy 2013, 5, 202-214. [CrossRef]

53. Kuzyakov, Y.; Subbotina, I.; Chen, H.; Bogomolova, I.; Xu, X. Black carbon decomposition and incorporation into soil microbial biomass estimated by C-14 labeling. Soil Biol. Biochem. 2009, 41, 210-219. [CrossRef]

54. Lehmann, J.; Abiven, S.; Kleber, M.; Zimmerman, A.R. Persistence of biochar in soil. In Biochar for Environmental Management; Lehmann, J., Joseph, S., Eds.; Earthscan, Tailor \& Francis Group: Washington, DC, USA, 2015; pp. 235-281.

55. Atkinson, C.J.; Fitzgerald, J.D.; Hipps, N.A. Potential mechanisms for achieving agricultural benefits from biochar application to temperate soils: A review. Plant Soil 2010, 337, 1-18. [CrossRef]

56. Warnock, D.D.; Lehmann, J.; Kuyper, T.W.; Rillig, M.C. Mycorrhizal responses to biochar in soil concepts and mechanisms. Plant Soil 2007, 300, 9-20. [CrossRef]

57. Chan, K.; Zwieten, L.V.; Meszaros, I.; Downie, A.; Joseph, S. Agronomic values of green-waste biochar as a soil amendment. Soil Res. 2008, 45, 629-634. [CrossRef]

58. Steven, F.V.; Kenar, J.A.; Thompson, A.R.; Peterson, S.C. Comparison of biochars derived from wood pellets and pelletized wheat straw as replacements for peat in potting substrate. Ind. Crops Prod. 2013, 51, 437-443.

59. Alburquerque, J.A.; Calero, J.M.; Barrón, V.; Torrent, J.; del Campillo, M.C.; Gallardo, A.; Villar, R. Effects of biochars produced from different feedstocks on soil properties and sunflower growth. J. Plant Nutr. Soil Sci. 2014, 177, 16-25. [CrossRef]

60. Ahmad, M.; Lee, S.S.; Dou, X.; Mohan, D.; Sung, J.; Yang, J.E. Effects of pyrolysis temperature on soybean stover- and peanut shell-derived biochar properties and TCE adsorption in water. Bioresour. Technol. 2012, 118, 536-544. [CrossRef] [PubMed]

61. Cantrell, K.B.; Hunt, P.G.; Uchimiya, M.; Novak, J.M.; Ro, K.S. Impact of pyrolysis temperature and manure source on physicochemical characteristics of biochar. Bioresour. Technol. 2012, 107, 419-428. [CrossRef] [PubMed]

62. Liang, B.; Lehmaan, J.; Sohi, S.P.; Thies, J.E.; Neil, B.O.; Turjillo, L.; Gaunt, J.; Solomon, D.; Grossman, J.; Neves, E.G.; et al. Black crabon effects the cycling of non-black carbon in soil. Org. Geochem. 2010, 41, 206-213. [CrossRef] 
63. Zavalloni, C.G.; Alberti, G.; Biasiol, S.; Vedove, G.D.; Fornasier, F.; Liu, J.; Peressotti, A. Microbial mineralization of biochar and wheat straw mixture in soil: A short-term study. Appl. Soil Ecol. 2011, 50, 45-51. [CrossRef]

64. Brodowski, S.; John, B.; Flessa, H.; Amelung, W. Aggregate-occulated black carbon in soil. Eur. J. Soil Sci. 2006, 57, 539-546. [CrossRef]

65. Chang, C.H.; Lehmann, J.; Thies, J.E.; Burton, S.D.; Engelhard, M.H. Oxidation of black carbon by biotic and antibiotic processes. Org. Geochem. 2006, 37, 1477-1488. [CrossRef]

66. Dotaniya, M.L.; Datta, S.C.; Biswas, D.R.; Kumar, K. Effect of organic sources on phosphorus fractions and available phosphorus in Typic Haplustept. J. Indian Soc. Soil Sci. 2014, 62, 80-83.

67. Glaser, B.; Lehmann, J.; Zech, W. Ameliorating physical and chemical properties of highly weathered soils in the tropics with charcoal-a review. Biol. Fertil. Soils 2002, 35, 219-230. [CrossRef]

68. Lehmann, J.; Pereira da Silva, J.; Steiner, C.; Nehls, T.; Zech, W.; Glaser, B. Nutrient availability and leaching in an archaeological Anthrosol and a Ferralsol of the Central Amazon basin: Fertilizer, manure and charcoal amendments. Plant Soil 2003, 249, 343-357. [CrossRef]

69. Uzoma, K.C.; Inoue, M.; Andry, H.; Fujimaki, H.; Zahoor, A.; Nishihara, E. Effect of cow manure biochar on maize productivity under sandy soil condition. Soil Use Manag. 2011, 27, 205-212. [CrossRef]

70. Liang, B.; Lehmann, J.; Solomon, D.; Kinyangi, J.; Grossman, J.; Neill, B.O.; Skjemstad, J.O.; Thies, J.; Luizão, F.J.; Petersen, J. Black carbon increases cation exchange capacity in soils. Soil Sci. Soc. Am. J. 2006, 70, 1719-1730. [CrossRef]

71. Pandit, N.R.; Mulder, J.; Hale, S.E.; Schmidt, H.P.; Cornelissen, G.; Cowie, A. Biochar from "Kon Tiki" flame curtain and other kilns: Effects of nutrient enrichment and kiln type on crop yield and soil chemistry. PLoS ONE 2017, 12, e0176378. [CrossRef] [PubMed]

72. Xiao, F.; Pignatello, J.J. Effects of post-pyrolysis air oxidation of biomass chars on adsorption of neutral and ionizable compounds. Environ. Sci. Technol. 2016, 50, 6276-6283. [CrossRef] [PubMed]

73. Tesfahun, W. Effects of biochar in soil chemical and biological property and mitigating climate change: Review. Civ. Environ. Res. 2018, 10, 58-61.

74. Jat, R.S.; Ahlawat, I. Effect of vermicompost, biofertilizer and phosphorus on growth, yield and nutrient uptake by gram (Cicer arietinum) and their residual effect on fodder maize (Zea mays). Indian J. Agric. Sci. 2004, 74, 359-361.

75. Kouas, S.; Labidi, N.; Debez, A.; Abdelly, C. Effect of P on nodule formation and N fixation in bean. Agron. Sustain. Dev. 2005, 25, 389-393. [CrossRef]

76. Jebara, M.; Aouani, M.E.; Payre, H.; Drevon, J. Nodule conductance varied among common bean (Phaseolus vulgaris) genotypes under phosphorus deficiency. J. Plant Physiol. 2005, 162, 309-315. [CrossRef]

77. Fairhurst, T.; Witt, C. Rice: A Practical Guide to Nutrient Management. Singapore and Los Baños; Potash and Phosphate Institute \& Phosphate Institute of Canada and International Rice Research Institute Philippines: Singapore, 2002; pp. 1-45.

78. Kumar, B.V.; Sreenivasulu, M. Integrated Nutrient Management. Sci Tech: The Hindu. India's National Newspaper, 12 August 2004.

79. Gruhn, P.; Goletti, F.; Yudelman, M. Integrated Nutrient Management, Soil Fertility, and Sustainable Agriculture: Current Issues and Future Challenges, 2020; International Food Policy Research Institute: Washington, DC, USA, 2000; pp. 1-3.

80. Hossaini, M.A.; Hamid, A. Influence of $\mathrm{N}$ and $\mathrm{P}$ fertilizer application on root growth, leaf photosynthesis and yield performance of groundnut. J. Agric. Res. 2007, 32, 369-374. [CrossRef]

81. Burman, U.; Garg, B.K.; Kathju, S. Effect of phosphorus application on cluster bean under different intensities of water stress. J. Plant Nutr. 2009, 32, 668-680. [CrossRef]

82. Ye, J.; Zhang, R.; Nielsen, S.; Joseph, S.D.; Huang, D.; Thomas, T. A combination of biochar-mineral complexes and compost improves soil bacterial processes, soil quality, and plant properties. Front. Microbiol. 2016, 7, 1-13. [CrossRef] [PubMed]

83. Lusiba, S.G.; Odhiambo, J.J.O.; Ogola, J.B.O. Effect of biochar and phosphorus fertilizer application on soil fertility: Soil physical and chemical properties. Arch. Agron. Soil Sci. 2016, 63, 477-490. [CrossRef]

84. Agegnehu, G.; Bass, A.M.; Nelson, P.N.; Muirhead, B.; Wright, G.; Bird, M.I. Biochar and biochar-compost as soil amendments: Effects on peanut yield, soil properties and greenhouse gas emissions in tropical North Queensland, Australia. Agric. Ecosyst. Environ. 2015, 213, 72-85. [CrossRef] 
85. Ulyett, J.; Sakrabani, R.; Kbblewhite, M.G.; Hann, M. Impact of biochar addition on water retention, nitrification and carbon dioxide evolution from two sandy soils. Eur. J. Soil Sci. 2014, 65, 96-104. [CrossRef]

86. Xu, H.X.; Weng, X.Y.; Yang, Y. Effect of phosphorus deficiency on the photosynthetic characteristics of rice plants. J. Plant Physiol. 2007, 54, 741-748. [CrossRef]

87. Sarker, B.C.; Karmokerand, J.L.; Rashid, P. Effects of phosphorus deficiency on anatomical structures in maize (Zea mays L.). Bangladesh J. Bot. 2010, 9, 57-60. [CrossRef]

88. Ahmad, M.; Wang, X.; Hilger, T.H.; Luqman, M.; Nazli, F.; Hussain, A.; Zahir, Z.A.; Latif, M.; Saeed, Q.; Malik, H.A.; et al. Evaluating Biochar-Microbe Synergies for Improved Growth, Yield of Maize, and Post-Harvest Soil Characteristics in a Semi-Arid Climate. Agronomy 2020, 10, 1055. [CrossRef]

89. Meena, K.N.; Pareek, R.G.; Jat, R.S. Effect of phosphorus and bio-fertilizers on yield and quality of chickpea. Ann. Agric. Res. 2005, 22, 388-390.

90. Singh, R.; Prasad, K. Effect of vermin-compost, Rhizobium and DAP on growth, yield and nutrient uptake by chickpea. J. Food Legumes 2008, 21, 112-114.

91. Ogola, A.H.; Odhiambo, G.D.; Okalebo, J.R.; Muyekho, F.N. Influence of phosphorus on selected desmodium growth and nodulation parameters. ARPN J. Agric. Biol. Sci. 2012, 7, 294-301.

92. Sulieman, S.; Tran, L.S.P. Phosphorus homeostasis in legume nodules as an adaptive strategy to phosphorus deficiency. Plant Sci. 2015, 239, 36-43. [CrossRef] [PubMed]

93. Balai, K.; Jajoria, M.; Verma, R.; Deewan, P.; Bairwa, S.K. Nutrient content, uptake, quality of chickpea and fertility status of soil as influenced by fertilization of phosphorus and zinc. J. Pharmacogn. Phytochem. 2017, 6, 392-398.

94. Singh, V.; Thenua, O.V.S.; Shivay, Y.S. Effect of phosphorus management on productivity of sunflower (Helianthus annuus L.). Prog. Res. Int. J. 2017, 12, 348-352.

Publisher's Note: MDPI stays neutral with regard to jurisdictional claims in published maps and institutional affiliations. 